Volume 113

Issue 1 Dickinson Law Review - Volume 113,

2008-2009

6-1-2008

\title{
After the Gold Rush-Part II: Hamdi, the Jury Trial, and Our Degraded Public Sphere
}

Daniel R. Williams

Follow this and additional works at: https://ideas.dickinsonlaw.psu.edu/dlra

\section{Recommended Citation}

Daniel R. Williams, After the Gold Rush-Part II: Hamdi, the Jury Trial, and Our Degraded Public Sphere, 113 DICK. L. REV. 55 (2008).

Available at: https://ideas.dickinsonlaw.psu.edu/dlra/vol113/iss1/3

This Article is brought to you for free and open access by the Law Reviews at Dickinson Law IDEAS. It has been accepted for inclusion in Dickinson Law Review by an authorized editor of Dickinson Law IDEAS. For more information, please contactlja10@psu.edu. 


\section{After the Gold Rush-Part II: Hamdi, the Jury Trial, and Our Degraded Public Sphere}

\section{Daniel R. Williams*}

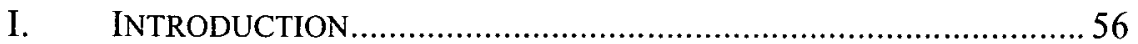

II. WE THE PEOPLE AND THE JUSTIFICATION FOR DETAINING

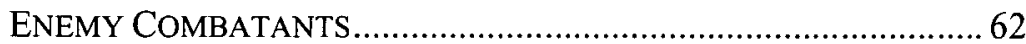

III. THE POLITICAL DREAM OF GUANTANAMO ................................ 70

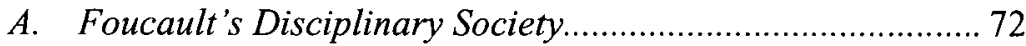

B. An MMDI World ........................................................... 76

IV. KANT'S DREAM OF UNIVERSALISM AND WEBER'S

NIGHTMARE OF THE IRON CAGE .................................................8 82

A. Our Criminal Adjudicatory Process as the Vitalizing

Expression of Our Enlightenment Heritage......................... 83

$B$. The Underbelly of the Enlightenment Heritage - the Weberian Nightmare ........................................................ 90

C. Habermas and the Public Sphere ...................................... 92

V. HAMDI WITHIN HABERMAS's SOCIAL ONTOLOGY ...................... 95

VI. HAMDI AS CULTURAL EXPRESSION ............................................. 106

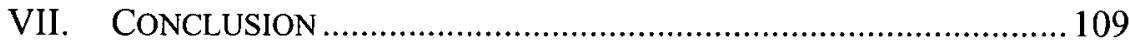

* Associate Professor of Law, Northeastern University School of Law. 
"Laws are born in the middle of expeditions, conquests, and burning cities."

\section{Introduction}

Long ago, in a bygone era of barbarism, cruelty, and darkness, before an Enlightenment era ushered in a human-rights consciousness, before the great revolutions created space for republican government to form and then flourish, there was the "spectacle of the scaffold." Punishment through horrific torture inflicted in the public square heralded sovereignty through "spectacle not of measure, but of imbalance and excess." 3 The public square became the forum for the sovereign, "through the body of the criminal," to reactivate its power: the scaffold in the public square "made the body of the condemned man the place where the vengeance of the sovereign was applied, the anchoring point for a manifestation of power, an opportunity of affirming the dissymetry [sic] of forces." ${ }^{\prime 4}$ The public sphere was where sovereignty announced itself.

As the public sphere changed its character through the transition of Western societies from a medieval age to a modernist one, punishment receded from view, with prisons sustaining rural economies, far away from crowded cities and suburbs. The trial and the judge's imposition of sentence became the symbol and expression of the penal justice system. The criminal-justice process, with the "trial" as its crown jewel-for the "trial" best exemplified a rationality invented in the Enlightenment erabecame the site not so much for sovereignty to manifest, but the arena for its limitation. The transition from the "spectacle of the scaffold" to a system of penality applying itself to a juridical subject, the possessor of rights, marks a corresponding transition in sovereignty itself, the great transition from the Monarch to the People. With this transition and the associated myth of the social contract to legitimate the state, law becomes the "fundamental manifestation of power."

1. Michel Foucault, Society Must Be Defended, in 1 Foucault, ETHICS: SubJeCtIVITY AND TRUTH 61 (Paul Rabinow ed. 1994) [hereinafter FouCAULT, ETHICS].

2. Michel Foucault, Discipline and Punish: The Birth of the Prison 32 (Vintage 1979) (1975) [hereinafter FouCAulT, Discipline AND PunISH]. For more on the idea of the "spectacle" as an integrated and diffuse apparatus of images and ideas that produces and regulates public discourse and opinion, see GUY DEBORD, SOCIETY OF THE SPECTACLE (Donald Nicholson-Smith trans. 1994) (1967) and GUY DEBORD, COMMENTS ON THE SOCIETY OF THE SPECTACLE (1990).

3. Foucault, Discipline AND PUNISH, supra note 2, at 49.

4. Id. at 55; see also id. at 110.

5. FouCAult, ETHICS, supra note 1, at 59. 
Part I of this two-part article series (After the Gold Rush-Part I: Hamdi, 9/11, and the Dark Side of the Enlightenment ${ }^{6}$ ) emphasizes the linkage between social consciousness and legal analysis, and thereby claims that our war-on-terror jurisprudence is a manifestation of a certain form of consciousness. ${ }^{7}$ Specifically, that article endeavors to show that Guantanamo-style detention, and the consciousness that goes with it (a belief in America as a normative concept, a consciousness I have termed, gold-rush American exceptionalism) ushers in and reinforces a resurgence of something akin to medieval sovereignty, not unlike the sovereignty that reactivated its own power through the spectacle of the scaffold. ${ }^{8}$ Hamdi v. Rumsfeld, ${ }^{9}$ as an exemplar of a burgeoning war-onterror jurisprudence, shows that the so-called war on terror is far from lawless; it is saturated with law, but not of the sort that merely manifests raw power. Law, the war on terror reveals, is a tactic of governmentality, an ingredient of biopolitics, an administrative tool where judicial power, in the case of Guantanamo detention, is exercised in disguised fashion (as "micropower," to use Foucault's terminology) through the discretionary acts of military personnel, from privates to

6. Daniel R. Williams, After the Gold Rush-Part I: Hamdi, 9/11, and the Dark Side of the Enlightenment, 12 PenN. STATE L. ReV. 341, 349 et. seq. (2007).

7. The idea of "consciousness" is complex and, within philosophical traditions, contested. I use the term in the rather uncontested sense of having the ability and unremitting drive to reflect upon one's own existence and place in the world. See Roberto Unger, KNOWLEDGE AND POLITICS 200 (Free Press 1984) (1975). Consciousness is what creates the subject-object separation that preoccupies Western philosophy. Id. This article borrows the Heideggerean view that human activity is best understood from the point of view of the beliefs and ideals of actors thrown into a particular moment in history. See generally MARTIN HeIDEGGER, BEING AND TIME (John Macquarrie \& Edward Robinson trans., Harper \& Row 1962) (1927).

8. Williams, supra note 6 , at, 349 et. seq. The core idea behind American exceptionalism, which allowed it to attain a firm grip within American intellectual culture, is the "assum[ption] that American society was not only good, but that it was itself a normative phenomenon." EDWARD A. PURCELL, JR., THE CRISIS OF DEMOCRATIC THEORY: SCIENTIFIC NATURALISM AND THE Problem of ViRTue 256 (Univ. Press of Ky. 1973). "In the seventeenth century the country was to be a city on a hill; in the eighteenth, the bastion of the Laws of Nature and of Nature's God; in the nineteenth, the last, best hope of man; and in the twentieth, quite simply, the great democratic success." $I d$. at 270 . The idea of linking this pax Americana consciousness to the development of a war-on-terror jurisprudence hinges on the presupposition that all social existence is linked to a form of consciousness: "[W]e never fully understand a phenomenon of consciousness... unless we can view it at the same time as a way in which men comprehend the world and organize their relations to one another." UNGER, supra note 7, at 108. Unger encapsulates the spirit of the analysis: "One's view on what is true of the world as a whole, or on how the language is in fact spoken, or on how the law on a given point stands cannot be cleanly separated from one's conception of the good, or of how the disputed point of law ought to be resolved. The perception of fact and the choice of values are joined together at the deepest levels of consciousness." Id. at 109.

9. Hamdi v. Rumsfeld, 542 U.S. 507 (2004). 
generals, who acquire their juridical authority, their micro-sovereignty, through legal decisions like Hamdi. ${ }^{10}$ So, not only is it misguided to critique Guantanamo detention as "lawless," but it is also misleading to over-characterize Hamdi and other war-on-terror cases as reflecting a struggle over judicial deference. Arguments over institutional power as a species of constitutional interpretation obscures the fact that violence at Guantanamo Bay is not executive violence only; it is judicial violence, too. ${ }^{11}$

This article, as a follow-up to the more internationalist focus of its predecessor, ${ }^{12}$ concentrates on things much closer to home-the justificatory basis for trial by jury, the state of our public sphere and our democratic culture, and ultimately the dangerous wholesale embrace of a means-ends rationality that threatens to undo completely the promise of the Enlightenment itself, which our own narrative of 9/11 tells us we are defending in this so-called war on terror. This article shares with its predecessor a focus on the resurgence of something akin to medieval sovereignty. ${ }^{13}$

Guantanamo-style detention, and Guantanamo as a symbol of a certain consciousness about American exceptionalism and the perceived rightness of U.S. domination in a globalized marketplace, suggests (albeit imperfectly) a return of the spectacle, and hence the repudiation of the Enlightenment understanding of penality-most notably in how Hamdi silently elides the central role trial by jury plays in vitalizing our Enlightenment heritage. Guantanamo-style detention is sovereignty manifested much in the way the scaffold in the public square is sovereignty manifested-both involve the sovereign's prerogative to make war on its enemies, to manifest its power against those who dare

10. For a full explication of "biopolitics," see 1 Michel FouCAULT, THE History of SEXUALITY, 135-59 (Robert Hurley trans., Vintage Books 1980) (1976) [hereinafter Foucault, SeXuality]. Foucault defines biopolitics as "the endeavor, begun in the eighteenth century, to rationalize the problems presented to governmental practice by the phenomena characteristic of a group of living human beings constituted as a population: health, sanitation, birthrate, longevity, race..." Michel Foucault, The Birth of Biopolitics, in Foucault, Ethics, supra note 1. See also JuRGEN HABERMAS, TowardS A RATIONAL SOCIETY 100 et seq (Jeremy J. Shapiro trans., Beacon Press 1971) (1968).

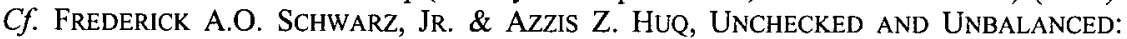
PRESIDENTIAL POWER IN A TIME OF TERROR 100 (The New Press 2007) (characterizing extraordinary rendition-an offshoot of "rendition," which has been a juridical device to "bring[] a suspect back to the United States for criminal trial"-as a "national security tactic").

11. For a discussion of law's violence, see Robert Cover, Violence and the Word, 95 YALE L.J. 1601 (1986). For a discussion of presidential lawmaking, which is key to the juridifying cloak draped over the so-called war on terror, see SCHWARZ \& HUQ, supra note 10 , at $105-08$.

12. Williams, supra note 6 .

13. Id. at $361-76,390$. 
challenge it. What Foucault says about the spectacle of the scaffold can also be said about Guantanamo: they both have a "juridico-political function" whereby a "ceremonial" is enacted by which "a momentarily injured sovereignty is reconstituted. It restores that sovereignty by manifesting it at its most spectacular." fitting that Guantanamo-style detention repudiates the Enlightenment notion of the potential detainee as a possessor of rights and of detention as the juridical deprivation of certain universally held rights (chief among them, the right to liberty, and potentially the right to life).

This repudiation of certain Enlightenment values, and the associated fetishism for others, will figure prominently in the presentation here. But we must avoid, at the outset, the pitfall of understanding Hamdi as being about the rights of a detainee. What makes a "detainee" not a prisoner is precisely the fact that a prisoner's rights have been suspended, or taken away, by an act of sovereignty made legitimate by the existence of a rights-holder insisting upon a legal process that accords with the Constitution; but the Guantanamo detainee's detention, brought about by a sovereign act of deeming an individual irredeemably dangerous (captured in the pseudo-legalistic term, "enemy combatant," or the geopolitical term, "terrorist"), does not involve the suspension of rights, because the detainee never was a possessor of rights in the first place. The core idea behind enemy-combatant detentions is the proposition that, when it comes to certain categories of danger, individuals lose their right to have rights; they become "bare life," to use Giorgio Agamben's terminology. ${ }^{15}$ What legitimates the detainee's detention is the enactment of an administrative process calculated to ratify the accuracy of the sovereign's deeming of the detainee to be a "terrorist." Deeming becomes a key expression of sovereignty. The administrative legitimation of enemy-combatant detention, which Hamdi accomplishes jurisprudentially, ${ }^{16}$ is the momentary fruition of an existing trajectory towards pervasive administrative control within a disciplinary society.

After the Gold Rush, Part I highlights as significant the fact that the Court in Hamdi never questions the sovereign's prerogative to deem who

14. Foucault, Discipline AND PUNish, supra note 2, at 48. That Guantanamo has become something more than a place, even in the consciousness of executive branch leaders, is captured in former Defense Department Secretary Donald Rumsfeld's order to "Gitmoize" the interrogation procedures at Abu Ghraib, the infamous Iraqi prison. Rumsfeld's directive, in essence, sought to intensify the harshness of the interrogations so as to gain the intelligence-gathering results allegedly achieved at Guantanamo. See SCHWARZ \& HUQ, supra note 10 , at 87.

15. Giorgio Agamben, Homo SaCer: Sovereign Power and Bare Life (Wemer Hamacher \& David E. Wellbery eds., Daniel Heller-Roazen trans., Stanford Univ. Press 1998) (1995). Cf. FouCAULT, SEXUALITY, supra note 10, at 135-59.

16. Hamdi v. Rumsfeld, 542 U.S. 507 (2004). 
is and who is not an "enemy combatant" or "terrorist"- that is, to classify an individual as one who possesses no rights, who has lost the right to have rights, other than a shallow prerogative to insist upon an administrative process that to some degree ensures that the classification itself is accurate (which, as a prerogative, is nothing more than delegating to the detainee a role that serves to improve the administrative decency of what is, underneath it all, rather indecent). ${ }^{17}$ That fact, significant in itself, is then linked to the claim that this enhanced sovereignty arises from a particular pax Americana vision that must be understood within the frame of our post-Cold War age of globalization. ${ }^{18}$

After the Gold Rush, Part I seeks to uncover a consciousness of American exceptionalism hidden within Hamdi, somewhat like the racial-superiority consciousness that exists hidden within McCleskey $v$. $K e m p,{ }^{19}$ the capital case where the Supreme Court rejected the Eighth Amendment challenge to the Georgia death penalty based on statistics showing a significant racial disparity in capital punishment. ${ }^{20}$ Within the storyline of the McCleskey opinion is the construction of two competing concerns: on the one hand, there is the unfortunate but amorphous risk of imposing the death penalty in a racially discriminatory manner, and on the other, there is the irreducible reality that the criminal justice system cannot exist without myriad acts of discretion. ${ }^{21}$ The risk of racial discrimination is entwined with the dream of racial equality that we as a society must pursue simultaneously in tension with the hard reality of the need for discretion in the criminal process. To capitulate to the risk, recast as but a dream and aspiration, is to crush the criminal justice system itself, for the pursuit of the dream of racial equality entails vanquishing acts of discretion that serve everyone as a solid, palpable reality. Dreams must give way to reality in the harsh world of legal

17. This right to insist upon a certain administrative integrity in classifying one an "enemy combatant" is only loosely a right of the detainee. It is more accurate to conceptualize it as a delegation to the detainee of a limited power to contest a governmental claim solely to facilitate the administrative process itself. The "rights" of the detainee are purely instrumental, as they exist only in their usefulness to the administrative task of designating who is and who is not an "enemy combatant." In saying that Guantanamo-style detention regards detainees as having lost the right to have rights, the term "rights" is used in the Kantian sense. See IMMANUEL KANT, GROUNDWORK OF THE METAPHYSIC OF MORALS 95 et. seq. (Herbert James Paton trans., Barnes \& Nobel, Inc. 1967) (1948); IMMANUEL KANT, LECTURES ON ETHICS 193-94 (Louis Infield trans., Harper \& Row 1963) (1930). Cf. SCHWARZ, supra note 10, at 85 (discussing U.S. torture policy, including Guantanamo detention, and noting the view of "executive branch leaders" that detainees do not "deserve" rights).

18. Williams, supra note 6 , at 401 .

19. 481 U.S. 279 (1987).

20. Id.

21. Id. 
decision-making. Racial equality is made ephemeral in the McCleskey storyline, a feature of Martin Luther King's "dream" that we celebrate at a designated time. ${ }^{22}$ World peace, with the United States submitting its sovereignty to international norms and laws, is like racial equality, a dream that we can wish for and pursue, but must give way-and with it, any investigation into the worthiness of the pax Americana vision that may threaten Legality itself-in the face of the harsh reality that is the war on terror.

This hidden pax Americana consciousness may explain why criticism of and activism against Guantanamo-style detention focuses almost exclusively on issues of process and evidentiary reliability. ${ }^{23}$ Hamdi was applauded for at least repudiating the push to give the Executive near-exclusive control over who gets summarily detained. ${ }^{24}$ The struggle since then has emphasized the importance of adhering to procedures, evidentiary procedures most of all, that promote accuracy in determining who is an "enemy combatant" and who is not. ${ }^{25}$ The result is that the humanitarian impulse that undergirds this struggle, by emphasizing administrative decency, may very well reinforce the background legitimacy of what Guantanamo-style detention seeks to accomplish for American interests in a twenty-first century era of globalization. War-on-terror jurisprudence is thus never pressured to consider the notion that Guantanamo-style detention does not serve the so-called war on terror, but that the war on terror serves Guantanamostyle detention.

Put simply, our American exceptionalism, as a fixture in our particular consciousness about who we are as a nation, seemingly blinds us to the more fundamental question: what precisely is the geo-political function of Guantanamo-style detention $?^{26}$ To avert terrorist attacks is the quick and instinctive, if not thought-circumventing, response that we accept largely because of this American exceptionalism-that, at least, is the suggestion in After the Gold Rush, Part $I .^{27}$ We accept that Guantanamo-style detention is an ingredient of a larger war on terror,

22. See Anthony G. Amsterdam \& Jerome Bruner, Minding The Law 202-16 (2000).

23. See Williams, supra note 6 , at 349 n. 26.

24. Id.

25. See infra at notes 141-142 and accompanying text.

26. To be sure, American exceptionalism and the pax Americana agenda is at the heart of the imperial executive project that scholars like John Yoo are pursuing. See, e.g., Jide Nzelibe \& John Yoo, Rational War and Constitutional Design, 115 YALE L.J. 2512 (2006). Yoo and others interpret Article II of the Constitution to favor Executive power so as to create the conditions for American empire. See John Fabian Witt, AngloAmerican Empire and the Crisis of the Legal Frame, 120 HARV. L. REV. 754, 770 (2007).

27. Williams, supra note 6, at 359, 405 et. seq. 
even if we hold the view that it is a foolhardy tactic or morally objectionable ingredient of that war. American exceptionalism, as a form of consciousness hovering over and coursing through the analytical veins of Hamdi, prevents us from even considering the possibility that the converse is more true: that the so-called war on terror is an ingredient of Guantanamo-style detention, that the larger project of pax Americana is captured in the detention practices at Guantanamo Bay, and that the "war on terror" exists in the service of what one scholar calls the "preexisting American empire-building project of global proportions." 28 The success or failure of Guantanamo Bay as a detention site, whether it remains or is shut down, is therefore incidental to a larger reality that it signifies: that globalization of a certain kind, with American economic interests as its pivot and those interests protected by unrivaled military dominance, is the telos of a historical progression that no political resistance, violent or otherwise, can derail.

This article shifts the focus but preserves the theme of After the Gold Rush, Part I. What is crucial in the transition away from the repellant use of public torture that characterizes medieval sovereignty, as Foucault evocatively describes it in Discipline and Punish, ${ }^{29}$ is the evolution of the public sphere into a place congenial to democratic institutions and practices. So long as we believe ourselves to exist within such a public sphere, we can hardly entertain the thought that we can retreat, or to some degree have retreated, into a form of sovereignty even remotely akin to medieval sovereignty. Hamdi endeavors to put a veil of administrative decency over a detention practice that signifies a resurgent sovereignty we thought had been buried long ago amidst the memory of the spectacle of the scaffold. It is worth contemplating whether that veil of administrative decency takes into account highly visible signs that the state of our public sphere betrays our consciousness about the public sphere and scarcely corresponds to what a democratic culture demands of it.

\section{We The People and the Justification for Detaining Enemy Combatants}

It is hard to know which is the greater tragedy - that, as the twentyfirst century begins, the United States approaches the world with a

28. Richard Falk, Identifying Limits on a Borderless Map in the First Post-modern War, in 11 SEPTEMBER 2001: WAR, TERROR AND JUDGEMENT 46 (Bulent Gokay \& R.B.J. Walker eds., Frank Cass 2d ed., 2003) (2002) (U.S. response to $9 / 11$ part of an "intensification of a pre-existing American empire-building project of global proportions").

29. FOUCAULT, DisCIPLINE AND PUNISH, supra note 2. 
drawn imperial sword, or that it discredits and disables its rich and in many ways unique republican traditions. ...

$$
\text { Jonathan Schell }{ }^{30}
$$

Here is the stripped-down institutional justification for detaining enemy combatants. Congress passed a bill, entitled the Authorization for Use of Military Force (AUMF), ${ }^{31}$ which in many ways is the contemporary version of the Roman senatus consultum ultimatum, the Roman senate decree authorizing Roman consuls to "take whatever measures they considered necessary for the salvation of the state. ${ }^{32}$ In granting through the AUMF similar authority to the Executive, ${ }^{33}$ Congress instantiates a state of exception, the bracketing of existing legal norms and injunctions, which is not at all unusual when a nation that considers itself peaceful (and what nation has ever thought otherwise about itself?) pursues military conquest. Rooting a state of exception in something like the AUMF - that is, linking the bracketing of existing legal norms and injunctions to legality itself - is a critical justificatory maneuver, as Walter Benjamin observed long ago:

What the law can never tolerate-what it feels as a threat with which it is impossible to come to terms - is the existence of a violence outside the law; and this is not because the ends of such a violence are incompatible with law, but because of "its mere existence outside the law." 34

With any inkling of violence existing outside the law there must immediately follow a thoroughgoing search for a regime of legality to either sanction or condemn it. The violence of Guantanamo brings with it precisely this search, and in Hamdi $v$. Rumsfeld the search yielded the AUMF. ${ }^{35}$ Finding some legislative enactment (a "law") to encompass the violence of enemy-combatant detention at Guantanamo Bay was urgent for less-than-obvious reasons. The obvious need for the search is the imperative to sanction the practice itself in order to preserve our claim of being a society governed by law. But there is more to it. To not find a source of legal authority would be to risk witnessing the infliction of state violence outside the law, with the legitimation of that violence

30. JONATHAN SCHELL, UNCONQUERABLE WORLD 386 (2003).

31. Authorization for Use of Military Force, Pub. L. No. 107-40, 115 Stat. 224 (2001). Congress passed the AUMF on September 14, 2001; the President signed it into law four days later.

32. AGAMBEN, supra note 15 , at 41 .

33. For a critique of the AUMF, see Williams, supra note 6, at 347-49, 405-07.

34. AGAMBEN, supra note 15 , at 53 (quoting Walter Benjamin).

35. Hamdi v. Rumsfeld, 542 U.S. 507, 510 (2004). 
resting solely on the political assertion of necessity. But necessity alone cannot ground violence, though it might (and does) ground a regime of legality that legitimates violence; if it were otherwise, if necessity were not absorbed into law, then necessity will vanquish law itself. State violence outside the law betrays a fidelity to the rule of law; when accepted within a society, it establishes a juridical ontology that is itself troubling. State violence outside the law establishes the existence of extra-legal violence which, in the end, fatally undercuts the foundation of legal violence. "The proper characteristic of [extra-legal] violence," Giorgio Agamben writes in his summary of Walter Benjamin's view of violence outside the law, "is that it neither makes nor preserves law, but deposes it." ${ }^{36}$ And so, Guantanamo violence, without the AUMF, would not merely be lawless; it would expose, in its pretense of legitimacy rooted in bare necessity, the ontological barrenness of the criminal justice system itself, the quintessence of legal violence in society. In that sense, Hamdi's invocation of the AUMF not only legitimates particular Executive activity, it more importantly preserves the criminal justice system itself, and all legality, from the vanquishing power of extra-legal violence. The AUMF brackets the criminal justice system in order to save it.

That might seem an odd conclusion. After all, according to a majority of the Justices in Hamdi, the AUMF includes the authorization to suspend the most vitalizing institutional embodiment of our Enlightenment heritage, the criminal justice process, with its crown jewel, the criminal trial. ${ }^{37}$ But that suspension is mitigated by the suggestion that this detention practice is extraordinary, exceptional, a consequence of what we might term a "state of exception" in which we find ourselves. The state of exception instantiated by the AUMF has come to be called the "war on terror." Detaining enemy combatants through the suspension of the criminal justice process is an aspect of that "war." It is important to grasp, at this point, that "war" is not a state of

36. AGAMBEN, supra note 15 , at 53 .

37. Hamdi, 542 U.S. at 517 ("agree[ing] with the Government's ... position that Congress has in fact authorized Hamdi's detention [without a jury trial], through the AUMF'). The criminal trial expresses, like no other social practice, our Enlightenment heritage. See infra notes $41-45$ and accompanying text. Regarded as tantamount to a civic religion, the criminal adjudicatory process expresses our Enlightenment heritage because, in so many ways, profound and prosaic, it institutionally embodies our distrust of authority and our valorization of the individual as a rational agent thus worthy of respect. When trial by jury finally displaced trial by ordeal and trial by oath, reason displaced faith as the guiding light of humanity. Reason became the legitimate authority to which a person may submit; and since reason is the province of each individual self, legitimate submission to authority is really the submission to one's own rationality. The so-called Apprendi revolution can be conceptualized as an effort to recapture this bedrock feature of the criminal trial. 
affairs or an observable circumstance, but more in the nature of an expression by government actors bearing the weight of sovereignty that a certain sovereign power must be exerted for the sake of the health and safety of the population: a form of biopower. Hence, one hears of "war" on poverty, or on drugs; we might recall President Franklin D. Roosevelt's "war" against the scourge of the Great Depression-these are significations of the exertion of sovereign power, a surge in biopolitical sovereignty. Here, the "war on terror," among other things, expresses through the Hamdi opinion itself an ambivalence over, even outright aversion to, the prospect of allowing trial by jury of persons whom we label terrorist, and thereby signals a specific surge of sovereignty-or, as one theorist puts it, a "resurgence" of sovereignty. ${ }^{38}$

So, the state of exception, as it might be understood in the context of Hamdi, consists of the Sovereign's prerogative, through the passage of the AUMF, to withhold from a U.S. citizen the legal status of criminal defendant, without disrupting or calling into question the legal category of "criminal defendant." Being indicted is not good news for the indicted individual, but it does confer upon him a certain legal status within a regime of law built upon the Fourth, Fifth, Sixth, and Eighth Amendments to the Constitution. The conferral of a legal status is a highly significant fact, not only for the indicted defendant, but for us, we the people, who absorb and propagate our identity as a nation. Yaser Hamdi wanted that legal status conferred upon him, wanted we the people to grant it to him, but the Sovereign refused-lawfully, the Supreme Court held, notwithstanding our nation's presumed commitment to limited government under law. ${ }^{39}$ The Sovereign's power to instantiate a state of exception, then, is a power of refusal, a refusal to maintain a citizen's integration within the existing political apparatus of the state, of which the criminal-justice system is a vitalizing part, and a refusal to maintain a citizen's integration within a community whereby that citizen's detention must be authorized by representatives of that community (i.e., a jury), unless that citizen lawfully consents to the detention (i.e., pleads guilty).

Because forcible detention must occur within some regime of lawbecause all violence must be subsumed within legality-Y Yaser Hamdi must be given some other legal status. No person can exist as bare life in the realm of political spectacle. Bare life must be clothed in some juridical garb. What garb does the Sovereign say Yaser Hamdi must drape over his bare life?

38. Judith Butler, Precarious Life: The Power of Mourning and Violence 54 (2004).

39. Hamdi, 542 U.S. at 534-35. 
The Sovereign has the power to do that, to drape some juridical garb over bare life, by saying what legal status shall be conferred upon the likes of Yaser Hamdi. The state of exception, as I use the term in this article, marks the conditions in which the Sovereign invokes its ability to withhold from a detainee the status of criminal defendant and to drape bare life with a new garb, a new legal status and category - that of enemy combatant. $^{40}$ The Sovereign can instantiate this state of exception, framed as a war on terror, with the associated authority to accomplish indefinite detention by withholding one legal status (criminal defendant) and replacing it with another (enemy combatant), because we the people consent to it, demand it even, as part of our expectation that the Sovereign, through the machinery of government, keep us safe.

The suspension of the criminal-justice process, and the expansion of sovereign power through the state of exception, is a price we are called upon to pay in the prosecution of this war. Actually, if we take democracy seriously, the tenor of my use of the term, Sovereign, as if the Sovereign were some actor in the world separate and apart from the subjects who are beholden to it, should seem jarring. The People as sovereign entity, rule-giver, and possessor of biopower, acts to protect the security of the people (the population itself, the actual living individuals who hear politicians speak sanctimoniously of "the People") by segmenting a certain slice of the people (designated as "enemy combatants" or "terrorists," or "sexual predator," or whatever category of dangerousness inaugurated by the People) and decreeing them ineligible for certain rights that are regarded as crucial ingredients in the identity of the People. If we take democracy seriously, it would then be more appropriate to say, without at all blushing, that this state of exception is a price we have willed upon ourselves, a price worked out by, so we tell ourselves, a re-calibration of the security-liberty balance. This recalibration is carried out for the benefit of the people within the branches of our government that are, so we tell ourselves, an organ of the People, in theory meaning, responsive to the will of the people. Congress and the Executive struggle over that re-calibration, and though it may not be elegant governmental activity, it is what our constitutional founders have bequeathed us.

The judiciary has a role, too, in this story of democracy in action. It engages in a different sort of calibration. It eschews this overt balancing of security and liberty, being too skittish to second-guess the People's decision to will upon itself a state of exception emanating from a

40. For the current legal definition of "enemy combatant," see Military Commissions Act of 2006, Pub. L. No. 109-366, creating 10 U.S.C. $\S 948 \mathrm{a}$ (1). For more on the etiology of the term, see Williams, supra note 6 , at $n$. 13. 
commitment to prosecute a war-even if it is a war unlike the wars we heretofore have fought or have read about in history books. The judiciary's calibration hones in on the mechanics of governance, the hard-wiring of governmentality that we have inherited from $1789 .^{41}$ The judiciary calibrates the allocation of power between the democratic branches of the American state so that those branches may, consistent with the rule of law, which could just as well be restated as consistent with our Enlightenment heritage, ${ }^{42}$ re-calibrate the security-liberty balance. The touchstone of the judiciary's calibration of this allocation of power is some appropriate vision of limited government under law. ${ }^{43}$ The idea of limited government under law, which is the core feature of our constitutional republic, owes its meaning, its force, and its very existence to Enlightenment political philosophy. ${ }^{44}$ So, when the Court in Hamdi struggles over this particular calibration-and the Court splintered over $\mathrm{it}^{45}$ - the Court is expressing our Enlightenment heritage and its underlying vision of law as the manifestation of power. Let us leave aside the irony that this expression of our Enlightenment heritage leads to the suspension of the most vitalizing institutional embodiment of that heritage - the criminal process rooted in trial by jury ${ }^{46}$-because the more important focus for now should be on the myopic nature of the Court's vision of limited government.

Hamdi reminds us that the constraints imposed on sovereign activity by our fidelity to the idea of limited government concern the mechanics of governmentality. ${ }^{47}$ What we pursue as a nation, rather than simply

41. See Samuel Issacharoff \& Richard H. Pildes, Between Civil Libertarianism and Executive Unilateralism: An Institutional Process Approach to Rights During Wartime, in The CONSTITUTION IN WARTIME: Beyond AlARMISM AND COMPLACENCY 162-81 (Mark Tushnet ed., 2005).

42. See Marbury v. Madison, 5 U.S. 137, 163 (1803) ("The government of the United States has been emphatically termed a government of laws, and not of men.").

43. See Curtis A. Bradley \& Jack L. Goldsmith, Congressional Authorization and the War on Terrorism, 118 HARV. L. REV. 2047, 2049 (2005) (noting the "outpouring of academic literature raising concerns about Executive Branch unilateralism and, in particular, about the absence of principled limits on Executive power to identify, target, detain, and try terrorists").

44. Our twentieth century cultural practices, and their institutional embodiments, are expressions of seventeenth and eighteenth century philosophical ideas. See generally ALASDAIR MACINTYRE, AFTER VIRTUE 36 et. seq. (2d ed. 1984) (1981).

45. See Williams, supra note 6 , at $346-49$ (discussing the plurality, concurrences and dissents in Hamdi).

46. A key grievance against the King of England specified in the Declaration of Independence was that "He has affected to render the Military independent of and superior to the Civil Power" and "deprived us, in many Cases, of the Benefits of Trial by Jury." THE DECLARATION OF INDEPENDENCE para. 14, 20 (U.S. 1776).

47. For a full explication of the term governmentality, see Michel Foucault, Governmentality, in MiCHEL FouCAult, POWER 201, 219-20 (James D. Faubian, ed. 1994) [hereinafter FOUCAULT, POWER]. 
what our government may pursue in its day-to-day operations to keep the bureaucracy functioning, is beyond the constraining idea of limited government, and thus beyond judicial purview. ${ }^{48}$ The idea of limited government, and thus the judiciary's own power, doesn't extend to the Sovereign's instantiation of the state of exception. But the juridical mechanics of how the state machinery is used to detain individuals as enemy combatants, as a defining feature of this state of exception, may be, to some as yet unclear degree, within the limited-government constraint and thus within the reviewing power of the courts.

What is troublesome with this picture-and what will herein be a continuation of a theme introduced in After the Gold Rush, Part I-is that the instantiation of the state of exception has become a technique of governance deployed in a globalization environment embroiled in a war of sorts that is unlike other "hot" wars we have experienced. It used to be that a "hot" war called upon the total mobilization of a populace, but no more, for this "war" depends on the acquiescence, or the passivity, of we the people. ${ }^{49}$ So, when the judiciary begs off the task of imposing the constitutional vision of limited government upon this particular technique of governance, when it too becomes part of the passivity that surrounds war-on-terror governmentality, it permits by omission what we are witnessing as the bloating of sovereign power-indeed, the eruption of a new kind of sovereignty. ${ }^{50}$ One might say, then, that because

48. See Samuel Issacharoff \& Richard H. Pildes, supra note 41 at 161 (observing that judiciary defers to security-liberty tradeoff made by legislative and executive branches). Whether we as a nation shall fight the Germans and the Japanese was never a justiciable question, but how the Sovereign may go about detaining American citizens who happen to be of Japanese descent is a matter of governmentality, or the valid operation of the machinery of the state. It turned out, of course, that in Korematsu the idea of limited government didn't have much traction. Korematsu v. United States, 323 U.S. 214 (1944). Same here, with respect to the so-called war on terror-our current state of exception-and the detention of so-called enemy combatants. See also Arar v. Ashcroft, 414 F.Supp. 2d 250, 283 (E.D.N.Y 2006) (officials who carry out extraordinary rendition cannot be held liable without congressional approval of damage suits). $C f$. Schwarz, supra note 10, at 47 ("[D]ebate[s] about a how a nation should conduct itself in a time of crisis must be framed in terms of national values.").

49. The war on terror is similar to the Cold War in that it traffics in conceptual simplicity - an us-against-them mentality-with us cast in the role of the noble heroes pursuing all that is right and good in the world, and "them," whoever that might be, so long as they are regarded as unvarnished evil with no coherent grievance. Like the Cold War, the war on terror gets the American people-and the Supreme Court, too-off the hook of actually trying to understand the world. Instead, opinions can be derived and analysis can proceed from a simplistic ontology that essentially bloats state power in the most crucial way, where the possibility of future human flourishing, if not human survival, hangs in the balance.

50. See Michael Hardt \& antonio Negri, Multitude: War and Democracy in THE AGE OF EMPIRE Xii-xiii (2004); see also SCHWARZ, supra note 10, at 65 et. seq. 
"sovereignty emerges within the field of governmentality,"51 Hamdi mocks the very idea of our commitment to limited government under law, which is the very foundation of our nation, and thus by extension disavows a crucial feature of our Enlightenment heritage. This disavowal is done in the name of preserving that heritage, or so we tell ourselves.

There is what many might consider a comforting response to this argument about bloated sovereignty. No suspension of law has taken place, one might counter, and thus no retreat from our commitment to limited government constrained by the rule of law. In fact, we can applaud the Hamdi Court for boldly swatting down the Executive's insistence that war silences law: "a state of war," Justice O'Connor writes, "is not a blank check for the President when it comes to the rights of the Nation's citizens." 52 More important, presumably, the instantiation of the current state of exception, which is the nation's commitment to prosecute a particular war against a technique deployed by a worldwide network of individuals unaffiliated with any state, is a matter of national will, and of national identity, that is reserved to we the people. So long as we take seriously the idea of American democracy, and so long as we believe that our democracy is working when it comes to the exercise of sovereignty in matters of global management (ubiquitously expressed in our political discourse as "spreading democracy"), we really cannot regard ourselves as the civil-rights-andcivil-liberties-losing victims of an overreaching Sovereign, because the state of exception itself, which is the juridical order brought about by a war on terror that we have democratically endorsed, is a product of our self-willing through the organs of our democracy. ${ }^{53}$

I find comfort neither in this response, nor in this entire story of democratic institutions re-calibrating the balance of security and liberty, as if that balancing takes place in a world that is simply handed to us, and is untouched by our own affirmative quests for domination and control unshackled by international legality. This fraudulent neutrality of the material setting in which the security-liberty balance is struck is the notso-deeply hidden backdrop of the Court's decision in Hamdi. Situating Hamdi within a story of democracy is dubious not simply because the "sovereign people, in its collective capacity, is everywhere and

51. BUTLER, supra note 38 , at 53 .

52. Hamdi v. Rumsfeld, 542 U.S. 507, 535-36 (2004).

53. "The law in a democracy matters because it reflects how the citizens choose to define themselves and their relationship to history; how it is they explain themselves to others. The law in a democracy is the citizen's means of communicating what type of nation theirs is to be." Michael Hatfield, Legitimacy, Identity, Violence and the Law (unpublished manuscript, used by permission). 
nowhere," a mythic symbol, as it were. ${ }^{54}$ It is not only that all such legitimation theories are rooted in fictions, or that "civil society is a bluff and the social contract a fairy tale." ${ }^{.55}$ The dubiousness is more empirical. What seems to be completely ignored in all the commentary about Hamdi and the other post-9/11 cases relating to the so-called war on terror is the rather stunning quiescence toward the real possibility that the United States, with its desiccated public sphere, has become "a military empire." ${ }^{.6}$ It is that quiescence, and the troubling circumstances surrounding it, that makes it so dubious to situate Hamdi in a storyline of democracy in action.

\section{The Political Dream of Guantanamo}

A central fact in Hamdi, if not the central fact, is the act of detention: a person is being confined, caged, and prevented from moving about freely. ${ }^{57}$ Secondarily to that fact is the asserted purpose behind that act of detention-namely, the averting of danger that the confined person poses to others. ${ }^{58}$ Detention, then, is a tool, and the use of that tool is, to some degree and in some manner, regulated by law. But what is the relationship of the tool and the law that supposedly regulates its use?

To consider that relationship, as was done in After the Gold Rush, Part I, I wish to borrow from Martin Heidegger's illustrative use of the hammer as a tool in Being and Time. ${ }^{59}$ Heidegger observes that human beings exist as beings-in-the-world, meaning we are thrown into it; we find ourselves in a certain time and living under certain limiting circumstances that are not of our own making or choosing. ${ }^{60}$ But as beings-in-the-world we have no choice, should we choose to live out a life, to do other than pursue projects. ${ }^{61}$ We have no choice, one might say, but to choose how we will reveal our own being as we move towards death. ${ }^{62}$ In that act of choosing, the environment in which we live (the world) consists of tools and instruments that we use to give

54. DiCK Howard, The SPECTER OF DEMOCRACY 212 (2002).

55. FOUCAULT, POWER, supra note 47 , at $\mathrm{xxxi}$.

56. Chalmers Johnson, The Sorrows of Empire: Militarism, SeCrecy, and the END OF THE REPUBliC 22 (2004); see also HARDT \& NEGRI, supra note 50.

57. See Williams, supra note 6, at 397 (discussing the actual situation of Yasser Hamdi as an incarcerated individual, and how his situation is reduced to an incidental backdrop to the legal issues in the case).

58. Id. at 397-405.

59. HEIDEGGER, supra note 7.

60. Id. at $68-69,78-90$.

61. Id. at 105-07.

62. Id. at 296-97. 
substance to our choosing. ${ }^{63}$ In that sense, our being is constituted by the world and the world is constituted by the myriad acts of choosing that take place every minute of every day. ${ }^{64}$

A hammer, we all know, is a tool. We also know its paradigmatic function - to bang in nails, or more generally, to strike other objects. Similarly, we presume to know the paradigmatic function of detentionas-tool-to incapacitate by confining. Heidegger insists on going deeper by distinguishing between an understanding of the hammer as a tool that is "on hand" and the hammer as a tool that is "at hand." 65 The hammer that happens to be "on hand" is inert, a thing lying there with a wood handle and iron head, having a specific measurable dimension and weight ${ }^{66}$ A hammer that is "at hand" is one that is being used-by a carpenter, say, who is building a cabinet. Our understanding of this thing we call a hammer is revealed by how it is being used. Its size and weight become more than just descriptive ingredients of the thing, but instead are matters of concern (is the hammer big enough for the job? is it too heavy?) We come to know the hammer more intimately in its "at hand" sense than we do in its "on hand" sense. We come to know the hammer through the medium of our chosen projects and engagements within a world that is constantly in the making by virtue of those projects and engagements. $^{67}$

What After the Gold Rush, Part I suggests is that Justice O'Connor in Hamdi treats detention-as-tool in the "on-hand" sense, as merely a thing that exists in society's toolkit for dealing with dangerousness. ${ }^{68}$ "Detention" as an "on hand" tool is a thing to be classified: is the detention at issue more in the nature of a civil commitment or a criminal punishment? Is it administrative or punitive? Much intellectual energy is devoted to making that classification, with no meaningful regard to understanding who is doing the detaining-who used in the widest sense of the term as, namely, this nation with a particular geopolitical aim (as if we can understand a hammer without understanding its use by a carpenter to build a cabinet or a house).

What the Heideggerian hammer suggests is that the more probing way of understanding detention is to treat it as an "at hand" tool, or an instrument used by a particular being (in this case, a nation) to pursue a set of aims (a being acting with intention), beyond the shallow aim of incapacitation. Detention as a tool that is "at hand" in the so-called war

63. Id. at $97-122,135-48$.

64. Id.

65. Id. at $98,190-95$.

66. Id.

67. Id.

68. Williams, supra note 6, at 377 et. seq. 
on terror cannot be adequately understood by examining it as if it were just something "on hand," as merely some thing that exists in a legal system's toolkit to defend against "danger" or to vindicate some notion of retribution. Examining it that way, and thus analytically focusing on how to classify the act of detention (is it civil commitment or punishment?) - a formal, dryly analytically exercise—obscures the truly urgent question, what exactly is this "tool" being used to accomplish geopolitically? It is either naive or an act of bad faith to suggest that Guantanamo detention is not a geopolitical tool of some kind. But what sort of geopolitical tool it is, and what sort of geopolitical aim is being sought through that tool, is entirely removed from the Hamdi analysis, as it is from the war-on-terror jurisprudence generally. These questions are not addressed because Hamdi analyses detention as an "on hand" thing rather than an "at hand" tool.

My project endeavors to create space for an analysis that treats Guantanamo detention as an "at hand" tool in this so-called war on terror. The spirit of that project rejects fundamentally the implicit image of Guantanamo detention as something that is simply inserted into the world, presumably out of a claimed necessity; Guantanamo detention is a representation of a social consciousness, exemplifying and acquiring its meaning and function from ideas and cultural forces that exist in the world, just as its existence ineluctably remakes the world. We cannot understand what it is that Hamdi was really deciding - that is, what is really at issue in that and other detention cases-without engaging in a Heideggerian "at hand" analysis of Guantanamo detention.

\section{A. Foucault's Disciplinary Society}

Civil commitment cases remind us of the ever-present temptationidentified by Foucault as emerging into view in the nineteenth century $^{69}$ - to bypass the obstacle course of criminal procedure in favor of the more streamlined approach that administrative processes allow. That we so often resist the impulse to dispense with the criminal process as the paradigm for detaining the dangerous raises the question whether we do so because we doubt our ability to accurately classify who is and who is not dangerous without the regime of rights associated with the

69. Michel Foucault, About the Concept of the "Dangerous Individual in Nineteenth Century Legal Psychiatry," in FouCAult, POwER, supra note 47, at 198-99 "'In the course of [the Nineteenth Century], penal law did not evolve from an ethic of freedom to a science of psychic determinism; rather, it enlarged, organized, and codified the suspicion and the locating of dangerous individuals. ..."); id. at 200 ("Only insidiously, slowly, and, as it were, from below and fragmentally, has a system of sanctions based on what one is been taking shape. It has taken nearly one hundred years for the notion of 'dangerous individual' . . . to be accepted in judicial thought."). 
criminal process, or because we remain fundamentally wedded to certain aspirations that only the obstacle course of the criminal process can vindicate. As much as we crave security, perhaps our need to impose moral blame is too resilient for us to capitulate too easily to the simplistic public-health-related administrative goal of detaining the dangerous. If we cling to our criminal adjudicatory process as the paradigm mode of determining who to detain, because there is a deep psychic need to express blame and to morally condemn, then our equally deep cultural aspiration, rooted in our Enlightenment heritage, to morally legitimate the condemnation in some Kantian fashion cannot be bypassed without provoking deep cultural and intellectual angst.

In Discipline and Punish, Foucault devotes a crucial chapter to what he calls "panopticism," which is an idealization derived from an architectural surveillance mechanism conjured up by Jeremy Bentham and called a Panoptican. ${ }^{70}$ The chapter opens, not with a description and discussion of the Panoptican, but with a narration of "the measures to be taken when the plague appeared in a town." 71 Foucault portrays a town that has become an enclosed, segmented space where the populace is constantly under observation: individuals "inserted in a fixed place" and their movements supervised, events recorded, and authority and power hierarchized. ${ }^{72}$ The town is a "compact model of the disciplinary mechanism"- $a$ mechanism of subjecting individual bodies to training, coercion, molding, and mobilization-inasmuch as "each individual is constantly located, examined and distributed among the living beings, the sick and the dead." ${ }^{\prime 3}$ What the plague brings about, on this narration, is the perfection of social ordering, the solidifying of the disciplinary ideal, which Foucault says is the hidden "political dream of the plague": "[T]here was also a political dream of the plague, which [involves] ... strict divisions; ... [and] the penetration of regulation into even the smallest details of everyday life through the mediation of the complete hierarchy that assured the capillary function of power."74

70. Here's Foucault's description:

[A]t the periphery, an annular building; at the centre, a tower; this tower is pierced with wide windows that open onto the inner side of the ring; the peripheric building is divided into cells, each of which extends the whole width of the building; they have two windows, one on the inside, corresponding to the windows of the tower; the other, on the outside, allows the light to cross the cell from one end to the other.

FouCAULT, DISCIPLINE AND PUNISH, supra note 2, at 200. One person within the central tower is thus in a position to observe, without detection, any one of the inhabitants of the cells in the peripheric building.

71. Id. at 195.

72. Id. at 197.

73. Id.

74. Id at 197-98. 
Apart from the political dream of the plague, Foucault identifies a separate phenomenon, which he introduces and analyzes in his first book, Madness and Civilization. ${ }^{75}$ This phenomenon involves the development of rituals of exclusion, starting with societal mechanisms of confining lepers and then later confining the socially useless (vagabonds, beggars, criminals, imbeciles, the insane); and later still, the refinement of the rituals of exclusion to isolate the "mad" as peculiarly in need of separation from the so-called "normal" society. ${ }^{76}$ The political dream of confining lepers and of the entire enterprise of exclusion, Foucault says, is "that of a pure community," and consists of naturalizing the "normal." T7 That political dream of naturalizing the "normal" differs from the political dream of the plague, as the latter consists of the dream of a "disciplined society" where the "normal" is not merely naturalized, but where individuals are molded into "normal" subjects, and where "normalization" takes place through disbursed networks of power. ${ }^{78}$ What is crucial for present purposes is not the details of Foucault's conception of "discipline," but the convergence of these two political dreams, where disciplinary mechanisms came to be applied with special force to spaces devoted to exclusion-i.e., places of confinement. ${ }^{79}$ Bentham's Panoptican epitomizes this convergence of the two political dreams, for it epitomizes "the existence of a whole set of techniques and institutions for measuring, supervising and correcting the abnormal," which in turn "brings into play the disciplinary mechanisms to which the fear of the plague gave rise." 80

What we may find useful to consider is the political dream of Guantanamo, already strongly evoked in After the Gold Rush, Part I as emblematic of the deep Enlightenment drive to control and dominate. ${ }^{81}$ That political dream partakes in a pax Americana vision of globalization, with gold-rush American exceptionalism at the core of a resurgent sovereignty akin to that which existed pre-Enlightenment. ${ }^{82}$ What

75. Foucault, Madness and Civilization 38-64 (Richard Howard trans., Vintage Books 1988) (1965).

76. Id.

77. FOUCAULT, DISCIPLINE AND PUNISH, supra note 2, at 198-99.

78. Id. at 199.

79. Foucault describes this convergence nicely: "On the one hand, the lepers are treated as plague victims; the tactics of individualizing disciplines are imposed on the excluded; and, on the other hand, the universality of disciplinary controls makes it possible to brand the 'leper' and to bring into play against him the dualistic mechanisms of exclusion." Id.

80. Id.

81. Williams, supra note 6 , at $417-23$.

82. Here is one articulation of the post-Cold War political dream, by two Bush Administration insiders, White House speechwriter David Frum and Defense Department official Richard Perle: "A world at peace; a world governed by law; a world in which all 
Foucault's work inspires is a corollary insight: Guantanamo Bay puts in place, as a present day reality, the entwining political dreams of the plague and of the leper. What lies behind Guantanamo-style detention, we might say, is the "haunting memory of 'contagions,' of the plague, of rebellions, crimes, vagabondage, desertions, people who appear and disappear, live and die in disorder." $" 83$ For what is this geo-political phenomenon we call "the Jihadi terrorist," but the grandiose and frightening expression of all these things, which must be excluded in every conceivable way and vanquished for the sake of society's wellbeing? What is Hamdi but a juridical expression of administrative necessity suitably veiled by administrative decency? Hence, the sound and fury of the legal issue boils down to, at the hands of the Hamdi Court, a mechanical application of Matthews v. Eldridge, ${ }^{84}$ and a roadmap of due process compliance to bureaucratic decisionmaking, arising from the sovereign's quest to exclude the quintessence of dangerousness-ideologically and religiously driven human missiles of destruction. What Hamdi reflects, then, is the larger cultural tendency to define practical problems as technical issues requiring technicians and experts (notably, so-called "foreign policy experts") rather than occasions for societal self-reflection. ${ }^{85}$

The ensuing discussion offers the following view: the war on terror started as spectacle, most notably, though not exclusively, through spectacular bombings aired with much fanfare on $\mathrm{CNN}$ and other news outlets, in Afghanistan and Iraq, and through leaked photographs of abject hooded detainees at Guantanamo; then, through the insistence upon administrative decency couched as due process in Hamdi, ${ }^{86}$ the war on terror is evolving into a form of disciplinary power that Foucault captures in his discussion of the town combating the plague. The political dream of the plague is the dream of the perfectly administered society, and it percolates in the Western rational mind with great vividness because the evil that the town combats presents itself in a

peoples are free to find their own destinies: That dream has not yet come true, it will not come true soon, but if it ever does come true, it will be brought into being by American armed might and defended by American armed might, too." DAVID FRUM \& RICHARD PERLE, AN END TO EVIL: HOW TO WIN THE WAR ON TERROR 279 (2003).

83. FOUCAULT, DisCIPLINE AND PUNISH, supra note 2, at 198.

84. 424 U.S. 319 (1976).

85. See, e.g., JuRgen Habermas, Towards a Rational Society 102-03 (J. Shapiro trans., 1971). Habermas warns against the ever enlarging range of issues removed from political debate and the treatment of those issues as technical problems best resolved by "experts." Id. Like Foucault, Habermas sees the trend in society towards an orientation that puts a premium on the "avoidance of risks and the eradication of the dangers to the system." DAVID Held, INTRODUCTION TO CRITICAL THEORY: HORKHEIMER TO HABERMAS 264 (1980).

86. Hamdi v. Rumsfeld, 542 U.S. 507, 534-35 (2004). 
simple dualism of life and death. ${ }^{87}$ Within the urgency of this life-anddeath struggle, the town devises mechanisms of social control and order (i.e., disciplinary mechanisms) to combat the evil of the plague. ${ }^{88}$ The political dream of Guantanamo is that same dream-the perfectly administered, highly rationalistic, society - and that dream, which hovers over Justice O'Connor's deployment in Hamdi of the due-process architecture of Matthews v. Eldridge, ${ }^{89}$ percolates again in our culture's consciousness and expresses itself juridically because we confront a lifeand-death struggle akin to that of the town's confrontation with the plague.

\section{B. An MMDI World}

The legal academy has dreamt the Foucaultian dream of the plague. $^{90}$ Consider Professor Albert Alschuler's scenario. Imagine the development of a psychological test that accurately assesses dangerousness. Alschuler calls this an MMDI diagnostic test. ${ }^{91}$ The state legislature requires everyone to take the MMDI and establishes a suitably high threshold score for the administrative detention of the intrinsically dangerous, a score that leaves very little doubt about the dangerous proclivities of the test-taker. ${ }^{92}$ The MMDI fulfills the dream of near-perfect preemption against dangerous individuals. We balk at this dream because in our waking hours we resist dispensing with the actstatus distinction. The civil-criminal dichotomy rests upon this distinction, and with it, our best efforts at regulating state power over the individual. $^{93}$

In Hamdi, the act-status distinction has been transmogrified from a shield against penal detention based strictly on dangerousness (i.e., status), into a sword wielded by the Sovereign to bypass the criminalprocess regime of rights. Hamdi presents the latest exemplar of the Sovereign exploiting the act-status distinction to address directly, outside the rights-regime associated with constitutional criminal procedure, the

87. FOUCAULT, DISCIPLINE AND PUNISH, supra note 2, at 198.

88. Id. at 199.

89. Matthews v. Eldridge, 424 U.S. 319 (1976).

90. Albert W. Alschuler, Preventive Pretrial Detention and the Failure of Interestbalancing Approaches to Due Process, 85 MiCH. L. REV. 510, 535 (1986).

91. Alschuler conjures up the fictional Menninger University as the site for the development of the Menninger Multiphasic Dangerousness Inventory test. Id.

92. Id.

93. See, e.g., Robinson v. California, 370 U.S. 660 (1962) (criminalizing status of narcotics addiction held unconstitutional). See generally Alschuler, supra note 90 , at 552 ("An insistence on proof of past misconduct shaped the common law's rules of detention as well as its definitions of crime."). 
issue of dangerousness. ${ }^{94}$ Yaser Hamdi's portrayal in O'Connor's storyline as a character who is acted upon and never genuinely acts, or an agent-less character, fits the juridical ambition of putting the case in the civil-commitment category and aids the narrative ambition of avoiding a confrontation with the reality of the ever-present temptation to bypass the cumbersome processes associated with criminal adjudication. ${ }^{95}$ Hamdi is simply not a case of culpable acts because whatever culpable acts Yaser Hamdi committed-acts replete with geopolitical significance-have been airbrushed out of the narrative by choice, but not by any intrinsic logic. ${ }^{96}$ Once that narrative goal has been accomplished, thus putting this case in the civil-commitment category, the conclusion seems analytically defensible that some meager menu of legal rights that accommodates individual and governmental interests suffices under the Constitution. The conclusion is more than just defensible, but actually is the height of nobility: "Because we live in a society in which '[m]ere public intolerance or animosity cannot constitutionally justify the deprivation of a person's physical liberty,' ... our [constitutional analysis] is unaltered by the allegations surrounding the particular detainee or the organizations with which he is alleged to have associated."97 Tolerance is thus deployed to reduce the legal controversy to the more prosaic question of how much process is due, rather than whether, and at what cost, Mr. Hamdi should be banished from the accepted regime of rights guaranteed to criminal defendants. After all, there must be thresholds of tolerance, and so, in this "war on terror," we must focus on whether you are with us or against us. ${ }^{98}$

94. See Kansas v. Crane, 534 U.S. 407 (2002); Kansas v. Hendricks, 521 U.S. 346 (1997); United States v. Salerno, 481 U.S. 739 (1987); Moyer v. Peabody, 212 U.S. 78 (1909). The Court, of course, hinted that terrorism might put the exclamation point on this line of authority. See Zadvydas v. Davis, 533 U.S. 678, 696 (2001) (leaving open the possibility that "terrorism" might justify "forms of preventive detention" for which the judiciary would have to give "heightened deference to the judgments of the political branches with respect to matters of national security").

95. See Hamdi v. Rumsfeld, 542 U.S. 507 (2004).

96. See id.

97. Id. at 531 .

98. Here we see evidence of what Derrida identified as objectionable in the notion of tolerance. It is a word with religious roots, deployed most often by "those with power, always as a kind of condescending concession." GIOVANNA BORRADORI, PHILOSOPHY IN

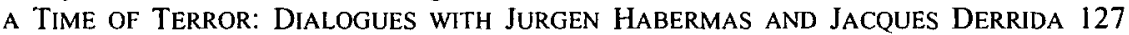
(2003). To Derrida, tolerance is a way of limiting one's welcome, a way of "maintain[ing] control over the limits of my 'home,' my sovereignty, my 'I can' (my territory, my house, my language, my culture, my religion, and so on)." Id. at 127-28. And so it is an attribute of sovereignty, "the good face of sovereignty, which says to the other from its elevated position, I am letting you be ... but do not forget that this is my home." Id. at 127. 
Hamdi, then, fits within a narrative that bespeaks a willingness to flirt with what I will here simply call an MMDI world, a world where the administrative determination of dangerousness is the primary good within detention jurisprudence, a world where, to quote Foucault's prescient observation, the juridical task "will be to reduce as much as possible-either by elimination, or by exclusion or by various restrictions, or by therapeutic measures-the risk of criminality represented by the individual in question." 99 Foucault's observations about the nineteenth century European mindset, that "criminality" evolved into a concept with "risk" of dangerousness at its core, ${ }^{100}$ is valuable here because it reinforces the overarching thesis that $9 / 11$ did not so much usher in something new, but unleashed cultural forces that were circulating within Western culture and consciousness for hundreds of years. On this view, understanding Islamic terrorists as human missiles of destruction, akin to lepers or carriers of the plague, is essentially the unleashing of the nineteenth century mindset of "the criminal [as] the social enemy." 101

The desire to use penal sanctions in the way that the Executive wishes to use enemy-combatant detentions and military commissions is very much a nineteenth century phenomenon, where juridical practices groped towards a coherent articulation of the "intrinsically dangerous" individual. ${ }^{102}$ "The entire penal regime of the nineteenth century became a control not so much over what individuals did-was it lawful or unlawful?-as over what they might do, what they were capable of doing, what they were liable to do, [and] what they were imminently about to do."103 The administrative design of enemy-combatant detention sanctioned by Hamdi is predicated on the judgment of an individual's potentialities, a juridical practice that, Foucault argues, characterizes many of our key institutions far beyond the courthouse, such as schools, hospitals, and prisons. ${ }^{104}$ This idea probably explains why one might balk at the wisdom of a policy to use Guantanamo-style detention, but at the same time not react in disbelief that such a practice

99. FouCaUlt, PowER, supra note 47, at 198.

100. Id. at 197.

101. MICHEL FOUCAULT, Truth and Juridical Forms, in POWER, supra note 47, at 1, 54. Associating dangerousness with disease also characterized the confinement of the insane, which ensued after the confinement of lepers waned after the Middle Ages. See FOUCAULT, MADNESS AND CIVILIZATION, supra note 75, at 205 (Richard Howard trans., Vintage Books de. 1988) (1965) ("Long before the problem of discovering to what degree the unreasonable is pathological was formulated, there had formed, in the space of confinement and by an alchemy peculiar to it, a melange combining the dread of unreason and the old specters of disease.").

102. FOUCAULT, POWER, supra note 47, at 198.

103. Id. at 56-57.

104. See FouCAULt, DisCIPLINE AND PUNISH, supra note 2, at 293-308. 
would even be conceivable. Hamdi presents a more intensive instance of such judgment, but there is nothing qualitatively different in the sovereignty expressed in enemy-combatant detention from what routinely happens in our disciplinary society. Hamdi is, in short, a fruition of an impulse that Foucault identified as salient some two hundred years ago.

The structures of exclusion, through which the Western impetus to detain and confine expresses itself, developed during the Middle Ages with the confinement of lepers, and then when that perceived danger abated, those same structures, having lain dormant, resurrected to confine those considered mad. ${ }^{105}$ Guantanamo-style detention, I suggest, exists within this Western tradition. More than that, Guantanamo-style detention perhaps reflects the potency of the sovereign's "biopower," a power over life, the administration of bodies and the rationalistic management of life, as opposed to merely a power to inflict death. ${ }^{106}$ Consider what Foucault suggests about capital punishment, that it is less about the sovereign's power to kill than it is about biopower: "[C]apital punishment could not be maintained except by invoking less the enormity of the crime itself than the monstrosity of the criminal, his incorrigibility, and the safeguard of society. One had the right to kill those who represented a kind of biological danger to others." 107 Does this not also hold true for how we seek to dispatch so-called Islamic terrorists? Is not the resurgent sovereignty at the heart of Hamdi rationalized and juridically managed in terms of this biopower? As we shall see later in this article, Hamdi exemplifies a means-ends style of reasoning suitable for a jurisprudence ensconced in an administrative state. It is therefore worth observing, pace Foucault, that with the advent of biopower as a feature of social life and governmentality, "law operates more and more as a norm, and that the judicial institution is increasingly incorporated into a continuum of apparatuses (medical, administrative, and so on) whose functions are for the most part regulatory."108 That is, law operates tactically within regimes of administrative control, Guantanamo detention being the most intensive manifestation of this fact.

Every act of judicial decision-making forges legal meaning, and the way that legal meaning is forged depends on the genuine commitment to some vision of a future reality, a "teleologic vision."109 With the advent

105. See FouCAULT, MAdNESS AND CivilizATION, supra note 75, at 204-05.

106. Foucault, SEXUALITY supra note 10 , at 140.

107. Id. at 138 .

108. Id. at 144 .

109. Robert Cover, Forward: Nomos and Narrative, 97 HARV. L. REV. 4, 45 (1983).

This commitment is quite real, no matter how dense the legal rhetoric may be to obscure 
of "enemy combatants" as a legal category, ${ }^{110}$ judges are tempted to commit themselves to a regulatory world where people are detained because they are looked upon as irredeemably dangerous-dangerous not for medical reasons, but for ideological reasons. That world to which such a commitment is made itself implies at least two secondary commitments, one relating to the commitment to the normal due-process regime for adjudicating criminal behavior, and another to a belief that whatever role our nation has played, and may still play, in producing the geopolitical frame that fosters the production of such dangerous individuals, that role is legitimate. The weaker the first, the less salient the second one must be. ${ }^{111}$

So, the expansion of sovereignty through a state of exception is not calculated to suspend law for its own sake. The criminal process as a regime of law, or as a form of legality, is suspended to create an anomic space for the Sovereign's construction of another regime of legality, and the effect of filling that anomic space with a new regime of legality (a new paradigm, if you will) is to limit the reach of the existing criminalprocess paradigm. What we get, ultimately, is a law of detention, with several branches all regulating the calculated management of life (biopower); the criminal process is but one branch of the jurisprudence of detention, perhaps eventually not even its most important, but merely the backdrop or starting point for understanding the law of detention, in much the way contract law is the starting point for understanding a whole host of specialized subjects, ranging from labor law to sports law to

it. Robert Cover speaks of the judge who must "choose between affirming his interpretation of the official law through violence against [authentic] protesters" who are committed to their own interpretation of the law. For the judge, the commitment entailed in enforcing her own interpretation of the law is "tested" by the naked fact that she is "part of the bridge that links the official vision of the [law] with the reality of people in jail." Id. at 48 .

110. For the etiology of the term, "enemy combatant," see Williams, supra note 6, at 346-47 n. 15 .

111. A bit more about the second commitment: Political resistance, whether it be from Al Qaeda or Eighteenth Century American colonialists, must occur through the articulation of reasons for the resistance. Those reasons may be outrageous or compelling, but they exist nonetheless as real things that give meaning to the commitment that is implied by the creation and enforcement of a particular doctrinal legal regime. It may be true that our nation is gripped by this "difficult time" as innocent victim and that Islamic fundamentalists are engaged in their own fanatical resistance struggle that warrants no serious intellectual attention. True or not, this view is a commitment to a particular vision of the world, and the creation and enforcement of the legal category of "enemy combatant" is part of the bridge that leads us from our present to that future. See Cover, supra note 109, at 45; see also BUTLER, supra note 38, at 92 (observing that our so-called war on terror is "transformed into a reality indefinitely extended into the future, controlling not only the lives of prisoners and the fate of constitutional and international law, but also the very ways in which the future may or may not be thought"'). 
landlord-tenant law to insurance law, etc. In the state of exception, the new paradigm suspends the old paradigm to vindicate the norm that animates the old paradigm. An enemy-combatant detention system (the new paradigm) - captured in the reality and idea of Guantanamodisplaces the criminal process (the old paradigm) to vindicate the norm of providing security because the old paradigm of the criminal process is not up to the task of vindicating that norm. In fact, the norm assumes its greatest intensity within the juridical vacuum created by the state of exception, thus making the need for displacement of the old paradigm seem undeniable. ${ }^{112}$ The displacement happens not outside of law, but within the juridical order, in this instance by eliminating the limiting principle in criminal justice that cases like Robinson $v$. California exemplify - namely, the analytical importance of the criminal act. ${ }^{113}$

Consider this remark, a typical sentiment, made by a member of the 9/11 Commission: "To put the matter in its simplest terms, the potential harm is so great that we can no longer wait until a crime is committed before responding."114 We see here what Agamben identifies as generally true in cases where a state of exception has been installed: we realize the norm (public safety) by suspending the application of the original paradigm that exists to vindicate the norm (the criminal adjudicatory process, with its emphasis on the act-status distinction). ${ }^{115}$ "That is, the state of exception separates the norm from its application in order to make its application possible. It introduces a zone of anomie into the law in order to make the effective regulation ... of the real possible."116 In the state of exception, the norm (security) is enforced even though the law (the criminal process) is suspended. Hamdi thus presents itself as Legality's effort to save itself, an exceptional and temporary effort to navigate this "difficult time" to restore viability of the normal paradigm. Legality contains within itself a form of antiLegality, a device to create a vacuum within Legality, within the juridical order that must not have a vacuum, in order to save itself against an external threat.

112. "On the one hand, the juridical void at issue in the state of exceptions seems absolutely unthinkable for the law; on the other, this unthinkable thing nevertheless has a decisive strategic relevance for the juridical order and must not be allowed to slip away at any cost." Giorgio AgAmben, STATE of ExCEPTION 51 (Kevin Attell, trans., Univ. of Chi. Press 2005).

113. See Robinson v. California, 370 U.S. 660 (1962); see generally HERBERT L. PaCker, The Limits of the Criminal Sanction 73-79 (Stanford University Press 1968).

114. John L. Farmer, The Rule of Law in an Age of Terror, 57 RUTGERS L. REV. 747, $756(2004)$.

115. See AGAMBEN, supra note 112 , at 36 .

116. Id. at 36 ; see also id. at 40 . 
IV. Kant's Dream of Universalism and Weber's Nightmare of the Iron Cage

September eleventh exposes a key duality in our culture: Kant's dream of universalism and Weber's nightmare of instrumentalist obsession.

The culmination of classical Enlightenment philosophy can be associated with Kant, the philosopher who most rigorously severed humanity from the yoke of blind obedience to authority by locating the source of all authority in the rationality of the individual. ${ }^{117}$ That rationality is the locus of personhood, and thus the locus of classical liberal Western human-rights discourse. For that rationality to carry the load that Kant places on it, the public sphere itself must foster it. Democracy and the Enlightenment go hand in hand in that respect: democracy is both the means for promoting the sort of autonomy and rationality that the Kantian tradition validates and the end result of a culture that commits itself to the Enlightenment project.

But within the promise of the Enlightenment heritage, a cancer lurks, ready to metastasize and destroy its host. Max Weber understood all too well the acute power of the Enlightenment's valorization of rationality; he understood how rationality could unleash a surge in technological and scientific achievements; and he understood the dark impulses upon which rationality, and the seductiveness of rationality, feeds itself. ${ }^{118}$ One philosopher summarizes Weber's critique of modernity in a way that meshes well with a key theme presented here, that what promotes the so-called war on terror is our Western obsession to control and dominate:

[The disenchantment of the world] leaves the human subject alone: as all ideals of cosmic harmony are dispelled, the world comes to be perceived as an external object to be used for utilitarian ends. Disenchantment is thus the breeding ground for an instrumental conception of rationality.... Reason, understood [in terms of means and ends], represents the pure and simple promotion of control-the control of human beings over the world and of the individual human being over others. ${ }^{119}$

117. See, e.g., ImManuel Kant, Groundwork OF THE Metaphysic OF MORAls 98109 (H.J. Paton trans., Harper \& Row 1964); M. HoRKhEIMER \& T. AdORNO, DialeCTIC OF ENLIGHTENMENT 81 (J. Cumming trans., 1972).

118. See HORKHEIMER \& ADORNO, supra note 119, at 4-42, 81-119; Held, supra note 85, at 65-66, 264.

119. BORRADORI, supra note 98 , at $69-70$. 
To understand how Kant and Weber play into the hidden forces swirling within Hamdi, we must first grasp the Kantian roots of our criminal adjudicatory process.

\section{A. Our Criminal Adjudicatory Process as the Vitalizing Expression of Our Enlightenment Heritage}

What, if anything, makes a criminal trial different from an administrative fact-finding tribunal? ${ }^{120}$ Addressing that question illuminates why the greatest expression of the Enlightenment ideal within the Kantian tradition is the criminal trial. It is where the ideal is most fully vitalized and where it is most forcefully put to the test.

We must immediately dispense with the view that a "trial" has some unitary, fixed meaning. As Judith Shklar observed long ago, "[a] trial, the supreme legalistic act, like all political acts, does not take place in a vacuum." how the juridical practice of putting someone on "trial" fits within a "whole complex of other institutions, habits, and beliefs," for a "trial within a constitutional government is not like a trial in a state of nearanarchy, or in a totalitarian order." ${ }^{\prime 22}$ I use the term here to refer to a juridical practice that takes place within a democratic culture that, at the institutional level, has been shaped by, and takes seriously, our Enlightenment heritage.

A consequentialist understanding of the criminal trial, with its focus on efficiently and reliably convicting the guilty, collapses the distinction: the instrumentalist justification treats the criminal trial as simply one embodiment of a fact-finding tribunal. The instrumentalist justification has a powerful gravitational pull in constitutional criminal procedure, for there is a constant tug in criminal-procedure doctrine to pursue administrative efficiency, which usually means curtailing the "rights" of the accused on the ground that those "rights" offer little payoff in terms of reliability and are too luxurious when security is our predominant concern. I put rights in quotes because the payoff for recognizing them-their cash value, so to speak-is ultimately what determines whether those "rights" actually exist as rights. This instrumentalist gravitational pull, however, struggles against a heavy anchor that grips our cultural soil. That anchor-in-the-soil is the word guilty.

A finding of guilt, rather than, say, factual responsibility, speaks to us in a language that resists the pull of instrumentalist reasoning. The

120. R.A. Duff, Trials and Punishments 33 (Cambridge University Press 1986).

121. Judith ShKLAR, LEgalism: LaW, MoRAls, AND POlitical TRIALS 144 (Harvard University Press 2d ed. 1984) (1964).

122. Id. 
announcement of guilt is not merely an epistemological claim, a claim of knowledge about what the accused has done; it is, more vitally, a moral statement, a condemnation, and an ontological categorization whereby the presumptively innocent accused becomes the convicted felon who must now undergo a penitential hegira (or, in rare cases, death). A criminal trial is fundamentally different from an administrative factfinding tribunal because what is expressed in a criminal trial is moral blame, and the state violence inflicted on the convicted felon arising from this moral blame requires a deeper form of justification than that required when mere fact-finding is the pursuit. Moral blame requires moral justification, and that moral justification must be built on the moral foundation that minimally respects the accused as a human being. Criminal adjudication differs from other modes of social control that rest on administrative or managerial motivations precisely in this outlook that we must have regarding the accused-that he must be accorded the moral status of a person. ${ }^{123}$ It is here, at the base of the moral architecture for our criminal adjudicatory process, that the Enlightenment ideals - the ideals of modernity, we might say-come into focus, thosesame ideals that are under assault in "this difficult time in our Nation's history." 124

No criminal trial is legitimate in our system of justice, no matter how accurate the outcome, without the participation of the accused in the process that may ultimately condemn him. ${ }^{125}$ That fact, in and of itself, reveals that internal to the very idea of a criminal trial is the understanding that it demands communication, rational argument and persuasion, not merely about the accused, but to the accused. "[T]he very meaning of the trial... [entails] a process of argument and judgment which is meant to be conducted with the defendant; a process which respects and addresses him as a rational and responsible agent who can be called to answer for his actions." 126

123. DuFF, supra note 120 , at $47,97,126$.

124. Hamdi v. Rumsfeld, 542 U.S. 507, 509 (2004); see also BORRADORI, supra note 98 , at 14 ("The explicit ideology of the terrorists who attacked the Twin Towers and the Pentagon on $9 / 11$ is a rejection of the kind of modernity and secularization that in the philosophical tradition is associated with the concept of Enlightenment.").

125. The accused may, of course, refuse to participate, or through obstreperous behavior forfeit the right to participate, but that refusal or forfeiture is itself a form of participation in that the accused's refusal or forfeiture manifests a choice on how to involve himself in the proceedings. The fact-finding tribunal may welcome the participation of the person who may be the target of the inquiry, but that participation is predominantly instrumental, for it is welcomed precisely to the extent that it enhances the tribunal's pursuit of an accurate outcome.

126. DUFF, supra note 120 , at 35 . 
This "answerability" thesis-that the accused must be addressed "as a rational and responsible agent who can be called to answer" 127 the charges-produces an adjudicatory process dedicated to engagement with the accused in a particular communicative endeavor, one rooted in the Kantian vision of the human being entitled to participate in rational discourse and argument. ${ }^{128}$ So, when we say that an accused is entitled to a trial, we are saying that the accused must be treated in a particular non-instrumentalist way, or in a way that respects his autonomy as a rational and responsible agent, worthy of communicative exchange. ${ }^{129}$

An instrumentalist vision of the trial, where the consequentialist focus on accurate outcomes predominates, does not justify adjudication by the quality of the communication between the collective and the accused; nor does it concern itself with the morally problematic act of coercing an autonomous individual, for the coercion is itself justified by the utilitarian calculus that punishment produces an improved state of affairs. But adjudication built on Kantian universalism puts the problem of coercion center stage.

An adjudicatory system dedicated principally to the epistemic function of disentangling the guilty from the innocent for the sake of promoting communal security necessarily rests upon coercion. ${ }^{130} \mathrm{~A}$ prison sentence is enforced against the individual's will for the sake of the common good: the criminal offender is forcibly removed from the community and coerced into living in a prison because we are all better off with that person in prison. Making sure that no innocent persons are coerced in this way for the sake of the common good is the most compelling side constraint to this system, and so the adjudicatory process implements accuracy-promoting devices to give us confidence that a guilty verdict is a valid claim to knowledge about the offender's

127. Id.

128. See id.

129. See id. Rooting the criminal adjudicatory process within a Kantian tradition ought not imply that this process must express in all respects a Kantian conception of justice, which in many ways is too severe for contemporary tastes. See Thomas PANGLE, The ENNOBLING OF Democracy 10-11 (The Johns Hopkins University Press 1992).

130. Coercion is the central problem for Legality, as H.L.A. Hart clearly saw, which is why his positivist theorizing strives to move beyond the Benthamite and Austinian accounts of law. See H.L.A. HART, ThE CONCEPT OF LAw 185-200 (Oxford University Press 1961). The naked positivism of Bentham and Austin cannot account for law as anything other than a system of coercion. Whether successful or not in dealing with the problem of coercion, Hart's positivism highlights both our anxiety over understanding Legality as ineluctable coercion and our passionate commitment to transcend that understanding. See id. Coercion is the central problem for the Enlightenment, too, which is why Legality and the Enlightenment are woven together as tightly as they are. 
culpability. ${ }^{131}$ This instrumentalist-epistemic justification, which uses utilitarianism to overcome the coercion problem, doesn't sit well with our commitment to Enlightenment values. Legality that offers only prudential reasons for compliance with law-follow the law or the state will impose unpleasant consequences upon you-is hardly a form of legality that harmonizes with Enlightenment notions of autonomy and respect. $^{132}$ In fact, a state that secures compliance with law purely through threats of sanction-indeed, a state that roots its existence through the power to enforce law-is by definition illegitimate. ${ }^{133}$ Kantian universalism overcomes the "coercion problem" by demanding that Legality secure compliance with law not through submission to power, but through legitimate obligation. ${ }^{134}$ Legitimate obligation rests on treating the individual as a rational agent who is entitled to have her obedience justified through rational argument: "The requirement that the law should address the citizen as a rational agent is ... integral to its character as an attempt to subject human conduct to the governance of obligation-imposing rules.... [The law's] claim on [the citizen's] obedience must be a moral claim which is justified to her in moral terms." $" 135$

What counts as a moral claim and what constitutes a justification offered "in moral terms" has long been regarded as an argument for the common good, whatever that might be. ${ }^{136}$ It is this fact of modernist thought that roots Legality in the concept of "community.", 137 In a society committed to Kantian universalism, criminal adjudication strives to justify itself by rendering criminal law as a system of obligations that binds everyone in a community. It cannot justify itself strictly as a mere process of filtering out the guilty from the innocent so as to promote security. It cannot justify itself as an effective way of detecting the dangerous. Criminal adjudication is not linked to the concept of community because it performs a function akin to a public-health inquiry where individuals carrying a dangerous communicable disease or virus are identified and forcibly detained. The concept of community is

131. See generally Alex SteIn, Foundations of EVIDENCE Law (Oxford University Press 2005).

132. See generally Robert PaUl Wolff, In Defense of ANARChISM 3-19 (Harper \& Row 1970).

133. Id.

134. KANT, supra note 117.

135. DUFF, supra note 120 , at 89.

136. See Rousseau, The Social Contract (Cambridge University Press 1997); DuFF, supra note 120, at 89-91, 148, 254-57.

137. DUFF, supra note 120 , at 89 ("For the law claims authority over a whole community, and imposes sometimes arduous obligations on its members: only by reference to the community's common good can the law's claims be justified to all its members."); see also id. at 254-57. 
central in criminal law because criminal adjudication must pursue more than just a diagnostic goal of isolating the dangerous, but must also pursue the goal of situating moral blame. Condemnation in criminal adjudication must therefore be more than an expression of power; it must also express the will to communicate, and to persuade offenders that they have offended against a norm and that, as rational agents, the offenders ought to will their own punishment. ${ }^{138}$

The criminal adjudicatory process, what we conventionally call "due process," is the institutional expression of moral blaming precisely because the community endeavors to justify a condemnation upon the individual:

For just as the law itself must be justified to those on whom it is binding, so too a criminal verdict must be justified to the defendant on whom it is passed. The aim of a criminal trial is not merely to reach an accurate judgment $o n$ the defendant's past conduct: it is to communicate and justify that judgment- to demonstrate its justiceto him and to others. ${ }^{139}$

Persuasion is key here. Blaming, the prelude to condemnation, is an invitation to argument: "[T] he proper aim of my criticism is to persuade [the accused] to see and to accept, not my judgment, but the truth about the moral character of his conduct; to engage with him in a search for and an attempt to understand that truth, not simply to force my own fallible and imperfect judgment on him."140

The jury trial, in this sense, is a vitalizing expression of the Enlightenment project because it partakes in the Habermasian ideal of communicative action-or, to use Habermas's own locution, "universal pragmatics"141 -in that the process of argumentation involved in such litigation entails the requirement to "redeem" every speech-claim with rational evidence that must, in the end, justify rational consensus of the community and the accused. What the jury trial thus expresses are the ambitions of a vibrant public sphere in a healthy democracy. And that expression, in turn, suggests that every instance where societal condemnation and punishment is re-conceptualized in an "MMDI" way threatens to corrode the societal commitment to this sort of public sphere.

So, the criminal indictment to which Mr. Hamdi felt entitled was to do more than hail him into court and inform him of the charges; it was to solicit him to argue against the accusation and, most critically, promise

138. Id. at 49.

139. Id. at 115 .

140. Id. at 49.

141. JuRgen Habermas, COMmunication and the Evolution of SOCIETy 1-68 (Thomas McCarthy trans., Beacon Press 1979) (1976). 
him that his own government will present rational arguments to persuade him as a rational agent that he is the offender and that his offense justifies the ensuing punishment. ${ }^{142} \mathrm{Mr}$. Hamdi wanted an indictment rather than a governmental deeming of him as an "enemy combatant," because the indictment starts a process of rational argumentation that "respects and addresses [him] as a rational and autonomous moral agent." 143

The moral power of Mr. Hamdi's demand rests with the fact that a democracy transcends the "coercion problem" by transmuting coercion into consent. We should see from all this how democracy as an ideal is entwined with the Enlightenment project: democracy ideally expresses that facet of the Enlightenment project which highlights autonomy and consent as superior to external authority and coercion. What the above discussion implies is that our criminal justice system, as an institution within a democracy, must itself express that same facet of the Enlightenment project. The intriguing thing here, of course, is that the institutional ambition of the criminal justice system, it's raison d'etre, which is the punishment of the guilty (sometimes with death), rests upon violence and coercion. For that reason, the criminal-justice process poses the greatest challenge of legitimacy upon our democratic culture, as it is within that institutional sphere that coercion and violence is most manifest.

The democratic ideal, then, is the moral basis for Hamdi's claim that he has a right not only to be tried in a criminal court, but also a right to be punished rather than merely locked away as an "enemy combatant."144 To be punished is different than to be detained, and that difference is juridically significant. The real power of Hamdi's claim is not, as is often assumed, that he is entitled to the sort of due process that characterizes criminal adjudication because we ought to be risk averse in our diagnosis of who are dangerous terrorists and who are not. It is also not that the obstacle course of due process better promotes accuracy. No, the real power lies in the fact that criminal adjudication, rather than the diagnostic inquiry into whether one is an "enemy combatant," is the only way to legitimize the exercise of state power against a citizen. The function of the criminal trial, on this account, is to vindicate what the

142. DuFF, supra note 120 , at 116 ("A trial, like moral criticism but unlike [an inquiry by fact finding tribunal], is a rational process of proof and argument which seeks to persuade the person whose conduct is under scrutiny of the truth and justice of its conclusions.").

143. Id. at 50.

144. See Herbert Morris, Persons and Punishment, 52 MonIST 475, 485 (1968) for an extended and classic treatment of this idea of the offender asserting the right to be punished. 
Enlightenment demands of the state: a justification for its own existence. Modernity creates a world of perpetual justification, a world where process must constantly express and vindicate a form of Legality that binds the citizenry through assent and not through manipulation or force.

So, what exists behind the veil of administrative decency that Hamdi propagates is our quandary about community, or about the depth of our commitment "to see the wrong-doer as a fellow member of a community from which his wrong-doing threatens to exclude him-a community made up of a complex web of social and personal relationships which structure our understanding of and our responses to each other's wrong-doing." "145 Guantanamo-style detention arises as a reality (indeed, even as a possibility) within a society harboring a consciousness about itself as a functioning democracy, because the war on terror creates the specter that our communities are in peril by irredeemably dangerous jihadists who can infiltrate undetected into them. It is the same dynamic that characterizes the surveillance and detention of sex offenders who have served their prison terms-remarkable abridgement of liberties outside the criminal-justice apparatus upon those who have already paid their societal debts because the community is haunted by the specter of the irredeemably dangerous sexual predator.

Detention of these sorts, outside the criminal-justice apparatus, depends upon the specter of the dangerous individual who must be segregated and confined in a fashion reminiscent of the way the town responded to the plague in Foucault's description of it in Discipline and Punish. ${ }^{146}$ It is a form of detention that amounts to a vanquishing of the danger. Whether the danger is of the plague, a deadly virus, the sexual predator, or the Islamic jihadist, vanquishing the danger and the dangerous is put in terms of survival. What Hamdi signifies, within this perspective, is a disciplinary society where administrative processes dedicated to some modicum of accuracy (couched as "rights") are all that we demand, not the indulgent and lumbering communicative tribunal that characterizes the criminal-justice process, no matter how that process might vitalize our Kantian Enlightenment values. For what worth are those values in the life-and-death struggle to vanquish the danger and the dangerous?

145. DuFF, supra note 120, at 61-62.

146. FouCAULT, Discipline AND PUNISH, supra note 2, at 198-99. 


\section{B. The Underbelly of the Enlightenment Heritage-the Weberian Nightmare}

What has heretofore given a patina of acceptability to this modernday Foucauldian "political dream of the plague" is the narrative idea of a wounded and vulnerable nation gripped in an existential crisis, seeking to protect itself against human "missiles of destruction." The descriptive (a threatened wounded nation) produces in this story the normative (the adjudicative assembly line for enemy combatants). The Foucauldian "political dream of the plague" is the Weberian nightmare.

In Dialectic of the Enlightenment, Frankfurt School theorists Horkheimer and Adorno identify the Weberian nightmare of obsessive instrumental rationality as the dominant cognitive orientation in Western culture. ${ }^{147}$ Whereas most Americans see as features of this means-ends orientation the awesome feats of science (the amazing technological prosthetics that drives humanity closer to becoming a God, as Freud observed), critical theorists like Horkheimer and Adorno saw what Weber saw ${ }^{148}$ - a cognitive orientation that feeds into and fuels our obsessive drive to dominate and control all that surrounds us. ${ }^{149}$ The salient point in the Dialectic of the Enlightenment, for our purposes, is that the instrumentalist orientation has been unleashed to devour the very idea of the "sacred" in life. ${ }^{150}$ September 11 th and the war on terror has only hastened a movement along an already existing trajectory.

What we experience in our alienated, gadget-filled, but spiritually vacant existence-what Max Weber termed our "disenchantment with the world"151 - is a reflection of what Horkheimer and Adorno diagnosed, and of how badly our capacity for reason has been corrupted by a fetish for means-ends rationality. ${ }^{152}$ That corruption, which is on

147. See HORKHEIMER \& ADORNO, supra note 117 , at xi.

148. The most powerful expressions of the Weberian nightmare, in my view, are William Faulkner's masterpiece, Absolom, Absolom!, Herman Melville's Moby Dick, and Cormac McCarthy's Blood Meridian.

149. See HORKHEIMER \& ADORNO, supra note 117, at 4. "What men want to learn from nature is how to use it in order to wholly dominate it and other men." Id. at 85 . See also HELD, supra note 85 , at 65 . This is not a left-right issue, notwithstanding the Frankfurt School's leftist orientation. New Deal liberals, in fact, are perfect exemplars of the instrumentalist orientation, committed as they are to the idea that reason can produce a form of social engineering that leads to greater social justice.

150. For one account of how our fidelity to science, to the point of treating it as our new religion, has destroyed our ability to comprehend sacredness, see WENDELL BERRY, LifE IS A MiRACLE: AN ESSAY AGAINST MODERN SUPERSTITION (2000).

151. HELD, supra note 85 , at 65 ; BORRADORI, supra note 98 , at 69 ; HORKHEIMER \& ADORNo, supra note 117 , at 4-7.

152. See HORKHEIMER \& AdORNO, supra note 117, at 6 ("For the Enlightenment, whatever does not conform to the rule of computation and utility is suspect."). See generally PANGLE, supra note 129, at 39-40 ("Rationalist society ... naturally tends to 
full display in the overt means-ends reasoning of Hamdi itself, has led to what philosopher Albert Borgmann calls a "crucial debility" in our culture, characterized by the "expatriate quality of public life" where we "live in self-imposed exile from communal conversation and action."153

There is, then, a certain blowback effect, where a mode of thinking that was supposed to lead to humanity's flourishing has been whipsawed back upon us as a powerful corrupting, even imprisoning, force. Whereas the Enlightenment, as exemplified by Rousseau, Voltaire, and Kant, promised freedom from irrationality and darkness, it has instead denuded the public sphere and bequeathed to us a technocratic language that debilitates the ability to conceptualize our way out of a disastrous course (ecologically and otherwise) on which our technocratic meansends orientation has put us. ${ }^{154}$

The quest for domination and control immanent within Enlightenment's fetish for means-ends reasoning, which supposedly promised a world of flourishing human rights (though pursued through the blood of ancient cultures, such as the native peoples in the Americas), drained modernity of the very vitality that modernist thinkers insisted

stress material welfare, while ignoring the spirit or soul," leading to a "spiritual barrenness"); Richard J. BERnStein, BEyOnd OBJECTIVISM AND RELATIVISM: SCIENCE, HERmeneutics, AND PRAXIS 189 (1985).

153. Albert Borgmann, Technology and Character of Contemporary life 3 (1984). The expatriation of public life is, of course, not a product of $9 / 11$; it is a feature of modern-day American life that evolved from the way life was lived in the nineteenth century in this young nation:

In the nineteenth century ... the organic interchange of the public and the private came under stress and was finally destroyed. Destruction came in the guise of ostentation. This was the time when department stores, libraries, and opera houses were erected as magnificent settings in which the public could gather and enjoy itself. But the people who filled these spaces had become silent, passive, and distracted. No longer actors and connoisseurs of public spectacles, they had begun to turn into recipients and consumers of commodities, produced for them by experts.

Id. at 41 .

154. See HORKHEIMER \& ADORNO, supra note 117 , at xi ("[I]nstead of entering into a truly human condition, [mankind] is sinking into a new kind of barbarism."). Wendell Berry encapsulates this idea:

The problem ... is that we are using the wrong language. The language we use to speak of the world and its creatures, including ourselves, has gained a certain analytical power (along with a lot of expertish pomp) but has lost much of its power to designate what is being analyzed or to convey any respect or care or affection or devotion toward it. As a result we have a lot of genuinely concerned people calling upon us to "save" a world which their language simultaneously reduces to an assemblage of perfectly featureless and dispirited "ecosystems," "organisms," "environments," "mechanisms," and the like. It is impossible to prefigure the salvation of the world in the same language by which the world has been dismembered and defaced.

BERRY, supra note 150 , at 8. 
was distinctive about Enlightenment society. ${ }^{155}$ It has instead taken us to the brink of annihilation in a world where the disparities of wealth are grossly appalling and human behavior slides so easily into barbarism and violence, usually in the service of preserving or further deepening those disparities. Whereas the Enlightenment broke the bondage of atrophied tradition, it has wrought a world where little is sacred, and what little remains is rapidly dwindling, where "what holds us all together is a cold and impersonal design." 156 We slaughtered cultures within our own country-Native American cultures that we still do not fully appreciate and comprehend-with the quintessential Enlightenment slogan, Manifest Destiny, only to bring about an ennui and despair that produces a nostalgic yearning for the sacred upon which those slaughtered cultures built their now-defunct way of life.

\section{Habermas and the Public Sphere}

The classic Frankfurt School diagnosis of American culture is grim and pessimistic. Jurgen Habermas rebels against the pessimism that pervades Dialectic of the Enlightenment, but he does not repudiate the essential diagnosis found there, though he surely seeks to deepen it with what he regards as a more nuanced investigation into the true roots of Enlightenment rationality. ${ }^{157}$ For our purposes, to this observation of humanity's destructive fetish with means-ends rationality, we may add Habermas's emphasis on the public sphere as an optimistic source of rationality. ${ }^{158}$ In the idealized vision that Habermas presents, the public sphere consists of voluntary associations dedicated to promoting unconstrained rational interchange among free and equal participants of good will. $^{159}$ It is in the public sphere, if truly healthy (free from the

155. BORRADORI, supra note 98 , at 69 .

156. BORGMANN, supra note 153 , at 3 ; see also HORKHEIMER \& ADORNO, supra note 117 , at 3 .

157. See Jurgen Habermas, Structural Transformation of the Public Sphere: AN INVESTIGATION OF A CATEGORY OF BOURGEOIS SOCIETY (1962) [hereinafter HABERMAS, StruCTURAL TRANSFORMATION]. Habermas's intervention into the discourse of $9 / 11$ is most interesting because his view of the Enlightenment as an unfinished project competes directly with the view, expressed by the intellectual foundation of the Jihadists we regard as our current enemy, that the "Islamic project ha[s] been left incomplete." BORRADORI, supra note 98, at 69. See generally IAIN BOAL, T.J. ClaRK, JOSEPH Matthews, \& Michael Watts, Afflicted Powers: Capital and Spectacle in a New AGE OF WAR (2006).

158. See Jurgen Habermas, Further Reflections on the Public Sphere, in HABERMAS AND THE PUBLIC SPHERE 441 (Craig Calhoun ed., 1992) [hereinafter Habermas, Further Reflections]; see also BORRADORI, supra note 98, at 13, 57-63; see generally HABERMAS, Structural Transformation, supra note 157; The Cambridge Companion to HABERMAS (Stephen K. White ed., 1995).

159. See sources cited supra note 158 . 
distortions of domination), that the common good can be gleaned. ${ }^{160}$ It is in the public sphere that government overreaching can be checked and averted. ${ }^{161}$ On this view, world public opinion, cultivated within vibrant public spheres that somehow escape the distortions of governmental and corporate propaganda, may function, in this post-Cold War era that has bled into the Age of Terror, as the only potential countervailing force to the dominant super-power, the United States.

What a vibrant public sphere provides are tools to resist naturalistic illusions undergirding social institutions and practices that preserve and promote spheres of inequality and regimes of domination, but that seem to be socially necessary. The idea here is well-rehearsed in the literature of critical theory: that which is socially constructed is made to appear fixed and natural; that which serves narrow interests of power and privilege is made to appear to serve everyone. ${ }^{162}$ A culture beholden to means-ends thinking is a culture that has lost its capacity for critical theorizing, and such a culture is, as a result, at the mercy of its illusions.

A vibrant public sphere that successfully exposes illusions, which conceal unhealthy conditions for society, is crucial to social change, for the exposing of such illusions is exactly what loosens the screws that keep unworthy social institutions intact. ${ }^{163} \mathrm{~A}$ vibrant public sphere is the environment for rendering institutions malleable and open to change, which is why thinkers from Kant to Habermas regard "the public sphere as the definitive institution of democracy." 164 The big problem, however, is that the "public sphere" in consumerist societies such as ours may itself have evolved into an illusion, propping up the justificatory myth that the Sovereign's activity is in check and in harmony with the consent of the governed. ${ }^{165}$ Consider the implications if we find, as an empirical matter, that the public sphere is beholden to the powerful and privileged but still retains the image of functioning largely in its idealized way. That false consciousness, to use a very unfashionable phrase, creates manifold opportunities for a bloated sovereignty-indeed, perhaps one like we are witnessing today-and a bloated sovereignty coexists nicely with a consumerist mentality that cannot seem to imagine any alternative to the present, other than a future that consists only of the present just with more snazzy gadgets.

160. See id.; see also Jurgen Habermas, What is Universal Pragmatics?, in COMMUNiCATION AND THE Evolution OF SOCIETY 1-68 (Thomas McCarthy ed., 1979).

161. Habermas, Further Reflections, supra note 158, at 446.

162. See generally HELD, supra note 85 .

163. See generally Roberto Unger, Democracy Realized: The Progressive Alternative (Verso 1998).

164. BORRADORI, supra note 98 , at 57 .

165. See generally BOAL, ET. AL., supra note 157 , at 34 ("[T]he dispersal and vacuity of the public sphere ... is necessary to the maintenance of "consumer society."'). 
Evidence abounds that this false consciousness pervades America today, with disastrous consequences. Vital issues of war and peace (let alone important issues revolving around health care, education, and economic well-being) are presented in stage-managed fashion, with vast sums of money spent on manipulating over-worked, anxiety-riddled consumerists who cling to an anachronistic, jingoistic, pre-Cold War understanding of what this nation stands for in the world. Voting is no longer the culminating act that follows a period of reflection and probing dialogue and debate, but rather voting is a reaction to "campaigns," operations not unlike military campaigns and Madison Avenue advertising campaigns, where the human commodity on display (the "candidate") has been selected largely through big-money donors and inside-power politics. ${ }^{166}$

If the hollowed-out nature of democracy captures something real in our culture, then is it really surprising that the great institutional embodiment of democracy and the most vitalizing expression of the Enlightenment, the right to trial by jury, has been under siege? ${ }^{167}$ And if

166. See HARDT \& NEGRI, supra note 50, at 231 ("The end of the cold war was supposed to be the ultimate victory of democracy, but today the concept and practices of democracy are everywhere in crisis."). The discussion in the text is not to be taken to imply a lost golden age. Far from it, American democracy, from the Fifties on, "was an institutionalized conflict between elites for political power, rather than any system of actual popular participation in the classical sense." PURCELL, supra note 8 , at 259 . In American-style democracy, "[l]arge-scale nonparticipation and apathy was socially beneficial, since it helped preserve democratic stability...."Id. Philosopher Albert Borgmann is particularly astute in showing that democracy has been hollowed out in American culture:

The nation's mood is sullen. Although such sullenness is to be found in most advanced technological countries, it here takes on a peculiarly American visage. It displays various qualities and manifestations. ... [This sullenness presents itself as an] inability to respond [to national problems,] as a sort of paralyzed irresponsibility.... This indolence appears not only in the irresponsible decisions of consumers and politicians but most fatally perhaps in the indifference of voters.

BORGMANN, supra note 153 , at 7.

167. On the surface it seems that the democracy-promoting function of the jury trial had reached its efflorescence in the so-called Apprendi revolution. See Apprendi v. New Jersey, 530 U.S. 466 (2000). But it is now clear that Justice Scalia's homage to the jury trial as a vitalizing expression of our democracy rests upon social conditions that are hardly congenial to the flourishing of the jury trial as a key ingredient in our detention practices. What this reflects is the broader point that ideas often reach their apex when the conditions producing them are already disappearing. See TERRY EAGLETON, AFTER THEORY 29 (2003). At the same time, the more firmly we root ourselves in a bureaucratic way of living, with ultimate priority given to instrumental reasoning, the more powerful is a practice like the jury trial, and the more deeply it holds sway in our imagination and our consciousness. Scalia's homage to the jury trial as a "circuit breaker" in our democracy can profitably be understood in this light. Our fidelity to the trial by jury, even when inconvenient, stands as a critique of, and warning against, our cultural obsession with instrumentalist modes of thought. Indeed, the more insistent we 
we abide the erosion of it, if we find that trial by jury cannot purchase its way into our culture because it cannot satisfy our quest for means-ends efficiency and because we have lost our vocabulary for noninstrumentalist justificatory ways of thinking and being, then what democratic institutions are next?

\section{Hamdi Within Habermas's Social Ontology}

The West confronts other cultures, which owe their character to the imprint of one of the great world religions, only through the provocative and trivializing aura of a banal materialistic culture.

Jurgen Habermas ${ }^{168}$

Habermas's social ontology illuminates what is at stake in our waron-terror jurisprudence, exemplified by cases like Hamdi. Habermas's theory of communicative action entails a society with two basic spheres, which he calls the "lifeworld" and "system" spheres. ${ }^{169}$ The lifeworld sphere-a construct Habermas acquired from Edmund Husserl, ${ }^{170}$ which roughly correlates with, but broadens, the concept of the public sphereconsists of those domains in life that we experience with our family and friends, our cultural life, our political life outside of organized politics (especially party politics), and our voluntary associations. ${ }^{171}$ The mass media, when performing independently of government and corporate interests, is part of the lifeworld sphere. Communication, participatory dialogue, and persuasion through reasoned discourse, as opposed to coercion, is the idealized medium of the lifeworld sphere. ${ }^{172}$ Consensus is the animating feature of the lifeworld sphere, which promotes human bonding, community integration, and value-sharing. ${ }^{173}$ The communicative action of the lifeworld sphere thus correlates with the "answerability" thesis discussed above, the non-instrumentalist understanding of the criminal trial as a process of rational persuasion, where even the accused, as a Kantian rational agent, is obliged to consent to her own punishment. It is that idealized integration of the accused with the judgment of the community that gives the criminal adjudicatory

are in adhering to it, especially in circumstances where "necessity" gives the practice a frame of extravagance, the more searing is its value as a critique of means-ends thinking.

168. JURGEN HABERMAS, THE DIVIDED WEST 12 (2006).

169. BORRADORI, supra note 98 , at 65 .

170. EDMUND HUSSER, THE CRISIS OF THE EUROPEAN SCIENCES AND Transcendental Phenomenology: An InTROduction to Phenomenological PHILOSOPHY (David Carr trans., 1970).

171. BORRADORI, supra note 98 , at 65 .

172. Id.

173. Id. at 65-66. 
process its preeminent moral standing in our Enlightenment culturepreeminent precisely because that idealized integration is most difficult in matters of crime and punishment.

So, as I have presented it here, the criminal adjudicatory process, in its idealized form, with trial by jury as the centerpiece to the paradigm of how the Sovereign justifies and legitimates the detention of the dangerous, both exemplifies and nourishes the lifeworld sphere. Each time a jury deliberates fairly and reaches an honest verdict, it presents itself as a beacon of the lifeworld sphere, where rational persuasion among free and equal persons is the bedrock value. Each fair and honest verdict nourishes the lifeworld sphere by strengthening our commitment to this mode of communicating with each other, even with those who have breached social norms in the most horrific ways. The more awful the crime, the more powerful is the fair and honest verdict in nourishing the lifeworld sphere. This idea perhaps explains, in part, why a criminal trial is usually more healing and more strengthening of a community, and hence more desirable, than a resolution through an administrative factfinding tribunal. The power of a fair and robust criminal process to heal and strengthen a community is emblematic of the larger point being suggested here, that instrumental rationality cannot bind a people together, but instead, when it predominates and seeps too deep into the culture, it ruptures what binds individuals, and leads to a passive consumerist individuality that characterizes modern American life.

Those who are familiar with the doctrinal struggles that take place within criminal procedure will understand that the criminal adjudicatory process is constantly being tugged out of the lifeworld sphere (where rights are understood as trumps) and shoved into the system sphere (where the barometer of fairness is accurate outcomes and where "rights" must purchase their way into existence by promoting reliable outcomes). ${ }^{174}$ The system sphere is much more recognizable because of how our capitalist economy developed and because of the particular way in which we have cultivated our Enlightenment heritage. The system sphere is characterized by communicative action motivated and prompted by instrumental reasoning; means-ends discourse is the language of the system world. ${ }^{175}$ The system sphere is the world of

174. For a good illustration of two competing visions of "rights" within constitutional criminal procedure, see, Strickland v. Washington, 466 U.S. 668 (1984). In Strickland, Justice O'Connor's majority opinion treats the right to counsel as tied to the accuracy of the outcome of the trial. Justice Marshall's dissent understands the "right" to counsel to be in the nature of a societal promise, thus leading him to conclude that deficient performance by defense counsel constitutes a Sixth Amendment violation regardless of the impact on the outcome.

175. BORRADORI, supra note 98 , at 66-67. 
governmentality and bureaucracy, where more rigid role-playing dominates how people interact. This is a sphere where language and meaning are instrumental in nature and where people are regarded as atomistic, self-interested, and consumeristic. ${ }^{176}$ The medium through which the system sphere operates in the United States is money and power. The more complex the society, and the more administrative and bureaucratic, the more important is the role of the system sphere in maintaining social cohesion. ${ }^{177}$

If that is true, then the Court's decision in Hamdi, as a cultural document rather than just a narrow jurisprudential one, ought to warn us about an important danger we face in our culture as we proceed further along towards the darkness that is the so-called war on terror. Kant identified two forms of rationality that roughly correlate with Habermas's lifeworld and system spheres: instrumental rationality situates the reasoning agent in a particular role with a predetermined end; universal reason (what we typically regard as Kantian rationality) frees the reasoning agent to use reason as an end in itself, which is the sort of reasoning process that undergirds the lifeworld sphere and the jury trial. ${ }^{178}$ In After the Gold Rush, Part I, I endeavor to show that the Hamdi Court takes on a role within the so-called war on terror-a role that seems so utterly natural, given our pax Americana consciousness, that it is virtually unnoticeable -that conceals how that so-called war exists to hasten the development of Guantanamo-style detention. ${ }^{179}$ The suggestion here is that this role with a predetermined end (winning the "war on terror," with no articulation of what "winning" means) propels the Court to use instrumental rationality to undercut the vitalizing expression of Kantian rationality. In this sense, Hamdi illuminates how deeply indeed we are at war with ourselves.

The implications are far-reaching. The more reductionist our language and the more reductionist our mode of adjudication, governed by instrumental reasoning alone, then the more mechanistic we become, not only in the legal "system" we use, but in the "system" sphere we inhabit, and thus in the consciousness we ultimately formulate. It is a consciousness in which "whatever does not conform to the rule of computation and utility is suspect." 180 The more mechanistic the

176. Id.

177. We might understand jurists like O'Connor to be largely wedded to the system sphere, with her fetish for outcome-determinative interpretations of constitutional rights. We might understand the United States Sentencing Guidelines and the pre-Apprendi jurisprudence to partake in the system sphere, too.

178. See Michel Foucault, What is Enlightenment, Foucault, ETHICS, supra note 1, at 307; see also HORKHEIMER \& ADORNO, supra note 117, at 83-84.

179. Williams, supra note 6 , at 377 , et. seq.

180. HORKHEIMER \& ADORNO, supra note 117 , at 6. 
consciousness, the more total is the power of the Sovereign, with the endgame being one that the world has already experienced, a systemsphere Nazi regime that embraced "the same kind of mechanistic thinking that, in an outwardly very different form, contributed to what most people would consider the glories of modern science."181 And lest we comfort ourselves with the view that the Holocaust is sui generis, an aberration in a Western culture imbued with an Enlightenment heritage that assures our essential goodness, we would do well to consider the Scottish poet Edwin Muir's observation:

Think of all the native tribes and peoples, all the simple indigenous forms of life which Britain trampled upon, corrupted, destroyed... in the name of commercial progress. All these things, once valuable, once human, are now dead and rotten. The nineteenth century thought that machinery was a moral force and would make men better. How could the steam-engine make men better? Hitler marching into Prague is connected with all this. If I look back over the last hundred years it seems to me that we have lost more than we have gained, that what we have lost was valuable, and that what we have gained is trifling, for what we have lost was old and what we have gained is merely new. ${ }^{182}$

The true spirit of trial by jury is the resistance against a mechanistic modality where means-ends consciousness is preeminent and where violence to accomplish control and domination, sweetened with nicesounding words (freedom, democracy) that have devolved into mere gestures, is too easily unleashed. The tension in criminal adjudication between this resistance and the attractions of instrumental rationality is no intrinsic feature of $9 / 11$, for that tension permeates, if not defines, the entire enterprise of criminal procedure. ${ }^{183}$

181. Erwin ChargafF, Heraclitean Fire: Sketches from a LifE Before Nature 4-5 (1978). See Jordan J. Paust, Executive Plans and Authorizations to Violate International Law Concerning Treatment and Interrogation of Detainees, 43 CoLUM. J. TRANSNAT'L L. 811 (2005) ("Not since the Nazi era have so many lawyers been so clearly involved in international crimes concerning the treatment and interrogation of persons detained during war.").

182. EDWIN MUIR, THE STORY AND THE FABLE 257 (1987).

183. Indeed, we may go further still, as the philosopher Judith Butler does when she knits together the growth of sovereignty and the expansion of governmentality:

$[P]$ rocedures of governmentality, which are irreducible to law, are invoked to extend and fortify forms of sovereignty that are equally irreducible to law. ... The suspension of the rule of law allows for the convergence of governmentality and sovereignty.... Law itself is either suspended, or regarded as an instrument that the state may use in the service of constraining and monitoring a given population; the state is not subject to the rule of law, but law can be suspended or deployed tactically and partially to suit the 
The more crucial the role of the system sphere in maintaining social cohesion, the more penetrating is that sphere's influence on human consciousness. The system sphere operates on and produces a consciousness beholden to means-ends thinking. This consciousness is peculiarly well-suited to a consumer culture where people are passive and manipulable by corporate and governmental interests. One might, in a very loose sense, correlate the duality of the lifeworld sphere and the system sphere with Jean-Paul Sartre's distinction between pour-soi (being-for-itself) and en-soi (being-in-itself)--roughly, human existence versus the existence of things. ${ }^{184}$ The lifeworld sphere promotes a person's embrace of his pour-soi character of his existence, his capacity for action, decision, and heightened consciousness. The system sphere tugs in the other direction, towards an en-soi consciousness, which is passive and more thing-like ${ }^{185}$ - a consciousness marred by a repression that leads to self-destruction and aggression. ${ }^{186}$

The system-sphere consciousness loses the ability to appreciate the sacred in life, the non-instrumental ways of being, producing what Arthur Koestler characterized as a "civilization in a cul de sac," an "everybody-for-himself civilization,"187 with masses who distract themselves with television and dim-witted movies, who understand and respond to the world amoeba-like as a source of pain and pleasure, and who cast about for cheap self-help recipes as a salve for a desiccated spiritual ennui. Role-players through and through, persons within an all-

requirements of a state that seeks more and more to allocate sovereign power to its executive and administrative powers. BUTLER, supra note 38, at 55 (emphasis added).

184. See Jean-Paul Sartre, Being and Nothingness 119-58 (Hazel E. Barnes trans., 1992) (1943).

185. $C f$. Francis Fukuyama, Our Posthuman Future: Consequences of the BIOTECHNOLOGY REVOLUTION (2002) (suggesting the logical endpoint of technological advances is the rendering of human beings into devices).

186. The contrast between the lifeworld sphere and the system sphere is reminiscent of Herbert Marcuse's treatment of aggression in human behavior. Marcuse formulated the problem of aggression in terms of a psychological and historical struggle between the forces of life and death. The only way to avert the destruction of humankind, by way of this aggression, Marcuse argued, is to restructure society in a way that permits the accumulation and release of erotic energy. This diagnosis and prescription had an anticapitalist component to it, as Marcuse believed that capitalism tended to localize eroticism in the genitals, thereby transforming the rest of the body into an instrument of labor. See Herbert Marcuse, Eros and Civilization (Beacon 1956). Presumably, an expanded, more vibrant lifeworld sphere would promote a form of sexual liberation that Marcuse might have approved of.

187. Morris Berman, Dark Ages America: The Final Phase of Empire 77 (2006); see generally PANGLE, supra note 129 , at 80 . For one of the original, and still most powerful, warnings of this trajectory in Western culture, see FRIEDRICH NIETZSCHE, THUS Spake Zarathustra, Prologue, sec. 5, in The Portable Nietzsche 128 (Walter Kaufmann trans., 1972). 
encompassing system sphere lose the ability to choose their own ends. That particular ability, the ability to express oneself authentically through the choosing of ones own ends in life, is the most redeeming feature of a healthy lifeworld sphere. Thus, it is here where the entwining relationship of the lifeworld and system spheres becomes crucial in critical theory. Habermas speaks of the system sphere as a product of the lifeworld, for the latter is the locus of energy and meaning-making in a society-things that the "system" needs to function. ${ }^{188}$ But the "system" sphere, that domain of instrumental reasoning where the impulse to control and dominate always percolates, has a greediness that is hard to contain. It can only be contained within a society that takes seriously the nurturing and empowerment of the lifeworld. Like the struggle between Eros and Thanatos, the struggle between the lifeworld and the system spheres always contains the threat that the latter will override"colonialize," to use Habermas's locution ${ }^{189}$-the former.

Many observers of American culture have warned against this colonization, which continues largely unabated. ${ }^{190}$ The mass media, properly in the domain of the lifeworld sphere, has been thoroughly hijacked by corporate power; education no longer serves a democratic culture where critical thinking is the pedagogical aim, but instead aims to produce the human wrenches and pliers, the spare parts, or the disposable accoutrements, of an economic machinery that serves narrower and narrower interests. Students entering college today are said to resort more often to cheating than previous generations, ${ }^{19 l}$ which is hardly surprising when the prevailing attitude among parents and students alike is focused on getting the credentials so as not to be on the outside looking in (a quintessential system-sphere consciousness), when almost

188. JuRgen HaBermas, The TheORy of COMMUNICATIVE ACTION 393-96 (1985).

189. Habermas, Further Reflections, supra note 158, at 446.

190. See, e.g., EAGLETON, supra note 167, at 123 ("Modern capitalist societies are so preoccupied with thinking in terms of means and ends... that their moral thinking becomes infected by this model as well."); BENJAMIN BARBER, JIHAD VS. MCWORLD 156 (1996) " "When the ethos of Disney becomes synonymous with the ethics of liberty and when consumers come to be seen as identical with citizens, genuine democratization is derailed."). The system sphere's colonization of the lifeworld sphere is often expressed in terms of the degrading and shriveling of the "public" space in American society, turning our nation into what Michael Sandel calls a "procedural republic." See MiCHAEL Sandel, Democracy's Discontent: America In SEarCh of a Public Philosophy 81 (1998); see generally WILL HUTTON, THE WORLD WE'RE IN 80 (2003); BORGMANN, supra note 153.

191. For discussions of student cheating see Sharon Cromwell, What Can We Do To Curb Student Cheating, EDUCATION WORLD, 2006, available at http://www.educationworld.com/a_admin/admin/admin375.shtml; Kate Zernike, With Student Cheating on the Rise, More Colleges Are Turning to Honor Codes, N.Y. TIMES, Nov. 2, 2002, available at http://query.nytimes.com/gst/fullpage.html?res= 9B03E1DA163EF931A35752C1A9649C8B63. 
every student shares the same major-upward mobility. More and more decisions that are vital to our health and well-being are delegated to experts who fill slots within vast bureaucratic apparatuses. More and more of life is removed from democratic control-a symptom of the shrinkage of the lifeworld sphere brought on by the colonization of the system sphere. What we experience, as a culture, is greater and greater anomie and alienation, erosion of social bonds, passivity, drug and alcohol abuse, and violence. The triumph of the system sphere and the withering of the lifeworld sphere manifests itself in the cozy bombshelter consciousness, where we had once accepted as rational the construction of livable bomb shelters as a suitable response to the specter of nuclear annihilation because we abandoned the capacity to critique the irrationality of the Cold War system that produced the threat in the first place. $^{192}$

The democratic project within our Enlightenment heritage insists upon a civic maturation where "the people" have the capacity and the willingness to use their own reasoning powers to govern themselves, as opposed to delegate governance to elites, charismatic charlatans, and socalled experts, all of whom ultimately serve narrower and narrower interests of privilege. ${ }^{193}$ It is hard to defend the view that American society has moved steadily in the direction of this civic maturation. We seem to be moving away from it, with a populace deeply manipulated by a "public relations industry, whose objective is to engineer consent among consumers of mass culture."194

192. Max Weber used another image which also captures the triumph of the system sphere, the image of an "iron cage, a prison of efficient bureaucratic blindness created by the indiscriminate growth of utilitarian and instrumental rationality." BORRADORI, supra note 98 , at 71 .

193. Immanuel Kant, An Answer to the Question: "What is Enlightenment?", in KaNT's Political WRITINGS 54 (Hans Reiss ed., H.B. Nisbet trans., 1970).

194. BORRADORI, supra note 98, at 57; see BERMAN, supra note 187; BARBER, supra note 188, at 163 ("Freely made choices are subject to marketing, merchandizing, advertising, and packaging influences, all of which ... are intended to shape, modify, divert, and even compel choices in the direction of what producers need to sell rather than of what consumers need to buy."). See generally, HORKHEIMER \& ADORNO, supra note 117 , at 120 et. seq. One legal scholar, in discussing how it is that we have come to accept as worthy of consideration the lawful torturing of other human beings, rightly emphasizes the degraded democratic culture we have created without the prompting of Al Quaeda or any other Jihadist committed to do us harm:

The electronic information and entertainment culture strengthens the mistaken responses to reality that justifying torture requires. With physical social world experiences being replaced by digitalized, isolated, smell-free, two-dimensional images over which Americans have instant and complete (remote) control, how can this not encourage feelings of complete control over reality? With TV and radio stations and web sites flooding Americans with data, information, opinions and political spin, how can this not encourage feelings of complete knowledge about reality? With endless cultural images of the good guys 
So here is the grim message that is intricated in the Hamdi narrative. At the very moment when it was most propitious to fortify a noninstrumentalist foundation for our commitment to trial by jury (and the other procedural rights that are associated with our criminal justice process) the Court does the precise opposite. ${ }^{195}$ It uses means-ends thinking to place a veil of administrative decency over what most now recognize to be a heinous practice in Guantanamo Bay. It endorses a style of thinking and a form of consciousness that is itself a key source of the problem we now find ourselves facing. If it is true, as Habermas presents it, that Islamic fundamentalism, and the terrorism associated with it, operates in a medium of violence arising from a "communicative pathology"-a "spiral of violence" rooted in a "spiral of distorted communication that leads through the spiral of uncontrolled reciprocal mistrust" ${ }^{196}$ - then our juridical response to it, culminating in opinions like Hamdi, replicates that "breakdown of communication" by bracketing the most crucial institutional embodiment of our commitment to rational and publicly transparent communication within our Enlightenment culture-the jury trial-and thereby sapping it of that significance. ${ }^{197}$ This reinforcing "communicative pathology" in this so-called Age of Terror presents the most pressing challenge to our crippled democracy.

The challenge of a healthy democracy is overcoming the very real danger that the form of consciousness that the system sphere operates on

overcoming bad guys simply because they are tough enough to do it, how can this not encourage individualism and determinism among us? Once we believe we know everything we need to know, and that our willingness to defeat evil is synonymous with our willingness to use violence, and we do not pause to ponder if we might be wrong, or if we might be ineffectual, or if we might not understand, the we are ready to torture. At that point, it's a mere syllogism to safety.

Michael Hatfield, Fear, Legal Indeterminacy, and the American Lawyering Culture, 10 LEWIS \& CLARK L. REV. 511, 526-27 (2006). See generally BOAL, ET. AL., supra note 157, at 21 ("The modern state ... has come to need weak citizenship."). Cf. SIGMUND FREUD, GROUP PSYCHOLOGY AND THE ANALYSIS OF THE EGO (1922) (noting throughout the willingness of individuals to yield unquestioningly to powerful external agencies).

195. I say "propitious" because our nemesis in this so-called war on terror implacably opposes our modernist culture. See BorRadori, supra note 98, at 14 ("The explicit ideology of the terrorists who attacked the Twin Towers and the Pentagon on $9 / 11$ is a rejection of the kind of modernity and secularization that in the philosophical tradition is associated with the concept of Enlightenment."); BARBER, supra note 190, at 22-23 ("America can spread a pop cultural civilization of movies, music, software, fast food, and information technology across the world until the world is reborn as McWorld, but it cannot control the blowback that is Jihad...."); id. at 62 ("[Islamic terrorism is the] product of toxic ideologies and religious fanaticism" and "historical circumstances ... to which, given its extraordinary military, economic, and cultural power, the United States has to some degree contributed - whether inadvertently or through explicit imperialist ambition or, most probably, some confusing combination of both.").

196. A Dialogue with Jurgen Habermas, in BORRADORI, supra note 98, at 35 .

197. BORRADORI, supra note 98 , at 19,35 . 
and produces-what I'll abbreviate as the consumer-consciousness, for that captures the passivity and manipulability of the system-sphere person-squeezes out the participatory-dialogue consciousness that is most congenial to the lifeworld sphere. ${ }^{198}$ Philosopher Albert Borgmann nicely captures the idea here, describing how the Enlightenment project seemingly placed the individual at the center of its ontology, but somewhere along the way led to the individual becoming "little more than an accomplice to a gigantic and systematic enterprise that, though resting on the consent of most people, was given a shape and momentum of its own." 199 The very power of the Enlightenment to produce magnificent technological prosthetics that "subdued and tamed reality" has reduced the individual self to the status of ignoble "consumer."200 The "consumer" is but an appendage to the system sphere, a mockery of the ennobled, high-functioning individuals who must populate the lifeworld sphere.

The state is too beholden to moneyed interest, or to corporate power, to ally itself with promoting the lifeworld. ${ }^{201}$ So government is not the solution to our cultural ills, but rather is one source of the problem, as it will do nothing to avert the relentless, inexorable expansion of markets and administration. The so-called war on terror, which in my view can be traced to that expansion, has only fueled the state's alliance with a system-sphere mentality. This may partly explain why "[s]ome say that ours is a world in which real democracy has become impossible, perhaps even unthinkable."202 In Habermas's social ontology, Hamdi falls smack in the middle of the system sphere. Yaser Hamdi struggled unsuccessfully to remain in the lifeworld sphere against the state's quest to extend the system sphere, a quest to intensify the exertion of sovereign power through executive and administrative powers. ${ }^{203}$ However, the Court cannot reconcile the Sovereign's desire to erect a simplistic, life-falsifying ontology that includes enemy combatants within a so-called war on terror with the juridical demand for due process merely by constructing a legal regime from certain

198. For a classic text on the role of consciousness and social change, see CHARLES REICH, THE GREENING OF AMERICA (1970).

199. BORGMANN, supra note 153 , at 79.

200. Id. at 79-80. See BORRADORI, supra note 98, at 57 ("mass consumption and its ideology, [and] consumerism ... silences rational-critical consensus. ...").

201. See BORRADORI, supra note 98, at 58 ("Maneuvered by multinational corporations and the unbridled free market, mass culture ... imposes its own rules of democratic participation: namely, utilitarian rules serving private interests rather than universal rules serving the public interest.").

202. HARDT \& NEGRI, supra note 50, at 18.

203. BUTLER, supra note 38 , at 56 . 
conceptual remnants picked out of Mathews $v$. Eldridge. ${ }^{204}$ The fact remains that Hamdi endorses and exemplifies the deployment of law to pursue a system-sphere logic-a means-ends rationality-of detecting and detaining bare-life beings who are deemed "dangerous." The Court repudiates trial by jury, which can only be justified ultimately through a lifeworld logic, at the very moment our commitment to it is most acutely tested. While civil libertarians applauded the Court's refusal to issue the blank check to the Executive, too many have ignored the sinister displacement of the most important expression of what is sacred in our Enlightenment heritage with a mode of reasoning that expresses that heritage's threatening dark side. ${ }^{205}$

We falsify the real force of that displacement by marginalizing it to the realm of some state of exception, as opposed to seeing it as a fortification of a certain global ambition on the part of the United States that continues to be unexamined within the juridical realm, despite the fact that what is supposedly sacred in that realm-an entire framework of rights that serve as genuine limits to governmental power-is precisely what must be protected by our courts. ${ }^{206}$ It is indeed odd to affirm our commitment to the rule of law through the construction of a legal regime, at the hands of all three branches-which is the basis for some scholarly applause for Hamdi - that is itself prompted by a desire to jettison the very legal regime that is supposed to reflect our commitment to the rule of law. This is law as a shell game. ${ }^{207}$

One would think that the rule of law contains some limit to the Sovereign's ability to further confine the domain of a particular legal

204. Mathews v. Eldridge, 424 U.S. 319 (1976). Mathews v. Eldridge exemplifies a balancing methodology in constitutional analysis where the government's interests are assessed against an individual's liberty interests. See generally Owen Fiss, The War against Terror and the Rule of Law, 26 OXFORD J. OF LEGAL STUDIES 235, 244-45 (2006) (criticizing use of Mathews v. Eldridge in enemy-combatant-detention context); Jerry L. Mashaw, The Supreme Court's Due Process Calculus for Administrative Adjudication in Mathews v. Eldridge: Three Factors in Search of a Theory of Value, 44 U. CHI. L. REv. 28 (1976) (noting dilution of due process requirements in holding).

205. Owen Fiss gestures at this critique in his criticism of O'Connor's reasoning. See Fiss, supra note 204, at 244. He argues that O'Connor's "error was to ignore the distinction between two types of liberties-those that are guaranteed by the Constitution itself... and those liberties that people enjoy in society, but which are not constitutionally protected. ..." Id.

206. It has almost become commonplace to recognize that our courts are anemic in restraining the Executive in this climate of terrorist anxiety, notwithstanding high profile Supreme Court decisions like Rasul, Hamdi, and Hamdan. This is largely because torture and extraordinary rendition, and the policies that sanction those practices, evade judicial review and oversight. See SCHWARZ, supra note 10, at 88, 99 .

207. For another account of this shell-game feature of law, within the context of our so-called war on terror, see BUTLER, supra note 38, at 55-56. See UGo MATTEI AND LAura NAder, Plunder: When the Rule of LAw IS ILlegal 4 (2008) (describing ruleof-law rhetoric as "a cover, a camouflage, or as propaganda"). See generally id. at 10-34. 
regime, like the criminal justice system, and erect another. One would think that, before punting the issue of what is sacred within a constitutional democracy to the democratic branches of governmentIssacharoff and Pildes's "process approach" how far we have moved away from the political environment that the Founders knew, gripped now by partisan politics where political party affiliation is "a much more important variable in predicting the behavior of members of Congress vis-à-vis the President than the fact that these members work in the legislative branch., ${ }^{209}$ Gripped, indeed, by something far more frightening and ominous:

Our Congress has been hijacked by corporate America and its enforcer, the imperial military machine.... We have allowed our institutions to be taken over in the name of a globalized American empire that is totally alien in concept to anything our founders had in mind. I suspect it is far too late in the day for us to restore the republic that we lost a half-century ago. ${ }^{210}$

One would think that, as part of our self-identity as a nation, our highest Court would confront the most elemental question: by what framework of legality may the Sovereign decide that a United States citizen (or anyone, for that matter) is unworthy of the sort of communicative enterprise that our Enlightenment heritage rightly regards to be the sine qua non of respect for human dignity? Hamdi is but a recent example of the Court's disinclination to investigate who we are as a nation as part of its obligation to preserve the noble facets of our Enlightenment heritage, all in the name of eschewing the dreaded sin of putting the Good before Liberty. ${ }^{211}$ And so, rather than exemplify the triumph of the rule of law, Hamdi exposes its emptiness. ${ }^{212}$

208. Issacharoff \& Pildes, supra note 41.

209. Daryl J. Levinson, Empire-building Government in Constitutional Law, 118 HARV. L. REV. 950, 960 (2005); see also SCHWARZ, supra note 10, at 204 ("Democracy is compromised in this fractious, dollars-soaked milieu.").

210. Gore Vidal, Perpetual War for Perpetual Peace 158-59 (2002). Hamdan, the military-commission case, can be understood as the Supreme Court's insistence that Congress take a firm stand on what the Executive may do or not do in prosecuting the socalled war on terror. See Hamdan v. Rumsfeld, 548 U.S. 557 (2006). Oblique references in terrorism legislation, and ambiguities in what is authorized, are not enough to empower a President to do such things as try terrorists for war crimes through a military commission. Id. The animating idea here is that Congress must be explicit in what it authorizes the Executive to do and thereby hold itself accountable to the American public. The Hamdan Court impliedly puts its faith in a democratic culture that an honest appraisal suggests is severely damaged.

211. See SHKLAR, supra note 121, at 65 (discussing this wariness, couched as an "objection ... [to] an ideology of agreement").

212. Cf. MATTEI \& NADER, supra note 207. 


\section{Hamdi as Cultural Expression}

A tension exists ... between the dispersal and vacuity of the public sphere, which is necessary to the maintenance of "consumer society," and those stronger allegiances and identifications which the state must call on, repeatedly, if it is to maintain the dependencies that feed the consumer beast. Weak citizens grow too soon tired of wars and occupations.

$$
\text { Iain Boal, et al. }{ }^{213}
$$

For Enlightenment culture to flourish, and its humane values to maintain a grip on our institutions, our public sphere needs to be detoxified of the poison of consumerism. This is essential for the pursuit of rational engagement in the public sphere, for a detoxified public sphere is a crucial condition for Legality itself to survive. Legality not only expresses the Enlightenment ideal of rational engagement; it also depends on a broader culture of rational engagement to nourish itself. Institutions cannot exist to shape culture, but must arise from that culture to give expression to the ideal.

The corruption of Enlightenment culture through consumerism is what makes U.S. empire-building both possible and necessary: possible, because the citizenry are beguiled by the myth of American benevolence and exceptionalism-America as a normative concept; and necessary, because global hegemony is crucial to maintaining consumerism itself, which has its stranglehold on us precisely to the degree that it advances the narrow material interests of the privileged and powerful. ${ }^{214}$ At the level of rhetoric, radical Islamists pursue a form of jihadism that attacks our Enlightenment ideals because what they see is the dark side of that project, with its decadence, consumerism, and associated drive to destroy traditional ways of life and to dominate the world. Islamic terrorists are post-modernists in that sense, motivated in part by the meta-narrative of globalization in which the United States (and to a lesser extent, Europe) takes on the role of "privileged vanguard of an evolutionary process that applies to all nations." 215 Globalization, with the advent of instantaneous

213. BOAL, ET. AL., supra note 157 , at 34 .

214. "The globalization of markets and of the consumer mentality has meant that global reasoning is dominated by private consumerist logic rather than public civic logic." BARBER, supra note 190 , at 166 . See also MATTEI \& NADER, supra note 207 , at 18 (noting "the role of consumerism in the diffusion and final acceptance of U.S. values" and thus the "key to hegemony").

215. BERMAN, supra note 187 , at 64 . See generally JOSEPH STIGLITZ, Globalization AND ITS DISCONTENTS (2002); JOHNSON, supra note 56. 
global communication, heightens this fundamentalist revulsion and thereby further provokes spasms of violence. ${ }^{216}$ We may be seduced by the imagery of the religious fanatic spilling out from a madrasas in Pakistan or Saudi Arabia, existing on the far periphery of our gadgetfilled consumeristic world, indoctrinated to despise the West, and recruited and trained by $\mathrm{Al}$ Qaeda to become a killing machine. But that jihadist is a product of an intricate web of commerce that is rapidly deluding people from non-Western cultures of their traditions and forms of life, leading them into a cycle of wage labor and the pursuit of some modicum of consumer power, a cycle resting atop manufactured desires for those creature comforts and distractions that today seduce much of the world's population.

All this is why we ought to understand Hamdi, more broadly, as an early feature of a jurisprudence of globalization. Globalization produces not only a jurisprudence of globalized commerce, but it also produces a jurisprudence of detention-Hamdi being foundational in that development. That jurisprudence of detention produced by pax Americana globalization circles back to reform our domestic juridical understanding of detention. Guantanamo Bay as a detention site is not merely a feature of our so-called war on terror; it is another feature of an entire carceral system that stretches back to the seventeenth century and that Foucault powerfully dissects in Discipline and Punish. ${ }^{217}$ This is why Hamdi, by blessing Guantanamo-style detention with a veil of administrative decency, ought to be linked to a reality that this article gestures at, a portrait of consumerist decadence that is poisoning our culture and driving our foreign policy ${ }^{218}$ - and has for over a half century-to the point where we are on a collision course with fundamentalism of all sorts. ${ }^{219}$ The juridical response to this collision course is the rationalistic message to do it better, to accomplish the detention for the sake of preserving life with greater regard for the tragedy of making a mistake. Hamdi stands for an invigoration of a carceral system flourishing within a biopower-world, where the regulatory function of the law operates on the simplest binary opposition-the dangerous and the normal-and where the "normal" has become the Western consumer.

216. See generally LAWRENCE WRIGHT, THE LOOMING TOWER (2006); MiCHAEL SCHEUER, IMPERIAL HuBrIS: WhY THE WEST IS LOSING THE WAR ON TERROR (2004); MALISE RUTHVEN, A FURY FOR GOD (2002); BARBER, supra note 190.

217. FOUCAULT, DISCIPLINE AND PUNISH, supra note 2.

218. See supra notes $190,192$.

219. See Christopher Clausen, Making Sense of America, 78 VIRGNIA QUARTERLY REV. 278 (2002) (with a culture of "mass individualism," it is "[n]o wonder fundamentalists of every kind see us as a moral threat"). 
When lonely voices in Western culture lament that we are at war with ourselves, we might do well to understand it, at least in part, in precisely these terms, "for it is a sad fact that Western consumerism explodes like a land mine in the midst of the most disadvantaged layers of the world population., 220 That intensive, exploding consumerism either elicits from those who feel themselves outside the globalization promise a defeatist and dark spiritual reaction that history has taught is violence-prone, ${ }^{221}$ or it becomes "a kind of intellectual sedative that lulls and distracts its Third World victims while rich countries cripple them, ensuring that they will never be able to challenge the imperial powers." 222 The gaping, echoing silence in Hamdi is this crucial fact: "We are witnessing a real resistance to empire." 223

The instrumentalist side of Enlightenment thought, the Weberian nightmare of disenchantment with the world, and the narrowly tailored quest for administrative effectiveness, where sacredness is lost to the shallow seductiveness of regulatory success, technological achievement, and the spirit-killing hyperreality that is its telos, is the cognitive scaffolding of an empire that must always and everywhere use or threaten to use military force to guarantee the conditions for the functioning of the world market, all the while masking its violence with rule-of-law rhetoric. ${ }^{224}$ That militarized management of the global order has and will inevitably produce the blowback of terrorism, with the capture of "enemy combatants" who must be detained on the instrumental logic of security that chokes off the life-affirming values undergirding civil liberties and rights we once thought sacred to our identity as a nation. Trial by jury, the highest vitalizing expression of those life-affirming values, is sacrificed for the sake of a global policing

220. BORRADORI, supra note 98 , at 65 .

221. See BERMAN, supra note 187 , at 308 ("There are undoubtedly many reasons for the $9 / 11$ attacks, but the fear that the American technocultural wasteland will, via U.S. foreign policy and economic policy, overwhelm the Islamic nations surely has to be high on the list."); AMY CHUA, WORLD ON FIRE: HOW EXPORTING FREE MARKET DEMOCRACY BREEDS ETHNIC HATRED AND GLOBAL INSTABILITY 9 (2003) ("[T]he global spread of markets and democracy is a principal, aggravating cause of group hatred and ethnic violence throughout the non-Western world."); BARBER, supra note 190.

222. JOHNSON, supra note 56 , at 261.

223. BOAL, ET. AL., supra note 157 , at 167.

224. See MATTEI \& NADER, supra note 207, at 33 ("Developing and accomplishing unchallenged primacy of physical strength has produced much of the hegemonic position of the United States. Today the United States government spends more on its army than the aggregate nine countries beneath it in the ranking of the top spenders. Nevertheless, in a project of expansionism, force requires ideology to gain some consent both in the camp of the hegemonic power and among its victims. This is where the rule of law plays a crucial role."). 
operation that finds its raison d'etre in the preservation and spreading of a system-world consumerist way of being.

\section{Conclusion}

In After the Gold Rush-Part I, I claim that foreign-policy expertise is the same sort of fiction as managerial expertise. ${ }^{225}$ From that claim, I argue that judicial deference to the Executive in matters of foreign affairs is an overblown manifestation of our legitimate commitment to separated powers. $^{226}$ Judicial deference in the service of a moral fiction like "foreign-policy expertise" amounts to an avoidance of thinking substantively about rights and obligations and of confronting urgent globalization issues. The upshot is this: what is important to the Court in Hamdi is not the globalization issues that generate the controversy, but the maintenance of domestic orderliness and neutrality in the government's pursuit of its global ambitions. This concern for neutrality and orderliness manifests in the Court's institutional refusal to address the fundamental concern that Guantanamo-style detention exists not to serve the so-called war on terror, but the war on terror exists to serve Guantanamo. In that sense, the war on terror is really a war on ourselves, a form of auto-immune crisis, as Jacques Derrida characterizes it. ${ }^{227}$ Hamdi expresses our own internal war against the criminal-justice system, exhibiting not just our ambivalence about it, but our impulse to detach it from its Kantian moorings and to make it administrative, and tribunal-like. Just as our technological prowess on 9/11 was whipsawed back against us, thereby threatening to eliminate the distinction between war and peace, so too the fundamental anxiety we feel towards our criminal justice process is whipsawed back to strike us hard, causing us

225. Williams, supra note 6 , at 367 . For the same point, and undoubtedly conveyed more colorfully and effectively through satire, see CHRISTOPHER CERF AND VICTOR NAVASKY, Mission ACCOMPLISHED! OR How WE WON THE WAR IN IRAQ: THE EXPERTS SPEAK (2008).

226. Williams, supra note 6 , at 367.

227. See BorRADORI, supra note 98 (presenting Derrida's view that today's terrorism threat causes an auto-immune crisis-the immune system attacking the body itself). Cold War theorist George Kennan liked to cite Edward Gibbon's observation that the Roman Empire undid itself in attempting "to hold in obedience distant provinces." JOHN LEWIS Gaddis, Strategies of Containment: A Critical Appraisal of Postwar American NATIONAL SECURITY POLICY 47 (1982). As Kennan saw it, "the very process of trying to maintain an empire would, sooner or later, generate resistance sufficient to undermine it." Id. William Appleman Williams observed the same thing: "The traditional effort to sustain democracy by expansion will lead to the destruction of democracy." WILlIAM APPleman Williams, The TRAGEdy of AMERICAN Diplomacy 312 (2d ed. W.W. Norton 1972) (1959). Montesquieu argued similarly, contending that republics could not sustain liberty when their territorial expansion made them "imperial." See BARBER, supra note 190 , at 48 n.4. 
to unleash that other collective drive, the drive towards a form of governmental administration at the heart of Foucault's "political dream of the plague,",228 the drive to overcome inhibitions in constructing an MMDI system, and a drive that threatens the elimination of the distinction between civil detention and criminal punishment. Viewed from this prism, Hamdi is an emblem of how our legal culture, and indicative of how Western culture itself, has become paralyzed by an over-commitment to a form of system-sphere reasoning atrophied by a fetish for means-ends maximization.

The dark side of the Enlightenment, which has produced a mighty economic machine that is backed by incredible scientific and technological achievements, has created a world that for over a half century has existed on a precipice of annihilation. We are perhaps even more precariously situated, largely because the internal drive within our culture to measure most everything in terms of financial profitability-a drive unleashed by the Enlightenment project to control and dominateis a compulsion with such overwhelming power that the most economically benefitted inhabitants of this planet simply cannot see beyond their own short-term material interests for the sake of their own children and grandchildren. ${ }^{229}$ My point here is that this overwhelming cultural drive threatens the vital and already-eroded life-affirming foundation of our criminal-justice system.

What if we looked upon a legal process, such as the criminal-justice process, as an end in itself rather than as simply a means to adjudicate? What if a legal process elicits our allegiance because it expresses a particular form of human solidarity and community engagement? What if a legal process pursues a justification that warrants the assent of the losing party simply because that assent-ability is a good in itself? What if a legal process is a commitment, not a tactic or instrumental feature of governmentality or epistemic method? What if a legal process were a "fact" in our regime of legality-meaning, it exists in a way that justifies

228. FouCAULT, DisciPline AND PUNISH, supra note 2, at 197-99.

229. Chalmers Johnson can only hope that history will prove him to be alarmist when he offers his gloomy "diagnosis" of our country's future:

As militarism, the arrogance of power, and the euphemisms required to justify imperialism inevitably conflict with America's democratic structure of government and distort its culture and basic values, I fear that we will lose our country. If I overstate the threat, I am sure to be forgiven because future generations will be so glad I was wrong. The danger I foresee is that the United States is embarked on a path not unlike that of the former Soviet Union during the $1980 \mathrm{~s} . .$. . Because the United States is far wealthier, it may take longer.... But the similarities are obvious and it is nowhere written that the United States, in its guise as an empire dominating the world, must go on forever.

JOHNSON, supra note 56, at 13. 
itself rather than as an instrument for some other goal-and thereby becomes a source of value within our culture?

Habermas's reconstruction of "communicative competence"-his ideal-speech theory-helps illuminate the stakes in our war-on-terror jurisprudence. ${ }^{230}$ The point of Habermas's reconstruction is not so much to point the way to establishing a discursive utopia, but rather, to show that internal to the structure of speech is a telos, a direction for humanity to achieve truth, freedom, and justice. Ethics can be rationally grounded; facts and values, and theory and practice, can be made inseparable. Habermas's reconstruction provides a way to understand the jury trial, and the whole criminal adjudicatory process, as an idealized expression of a way of life, an anticipation of a way of life where truth, freedom and justice are possible. Internal to the criminal adjudicatory process is the answerability thesis, and internal to the answerability thesis is a set of values that we have come to regard as constitutive of who we are as human beings worthy of respect and dignity. The practice of adjudicating conflict through a jury trial-a practice that partakes in the construction of an ideal-speech situation-contains within it a telos for humanity, a telos that correlates with that contained in Habermas's ideal speech situation wherein "the truth of statements is linked in the last analysis to the intention of the good and true life."231 Hamdi, then, does not just bypass a fact-finding process, it denigrates the vitalizing aspect of the jury trial through a form of reasoning that is suffocating humanity and putting it on an irreversible path towards a brave new world. It does so through a framework of necessity that is linked to geo-political activity that must be understood without the distorting effects of an American exceptionalism that regards "America" as a normative concept.

\section{$* * *$}

What says it all is this 2004 testimony before the House Armed Services Committee. General James Hill, responsible for military readiness in Latin America, essentially complained of being ignored in this age of $9 / 11$ anxieties. His sphere of command ought to get more war-on-terror money, he argued, because Latin America is filled with "radical populists," by which he meant, "[y]ou know, emerging terrorists." 232 In the pursuit of empire, we are forever threatened by

230. See Jurgen Habermas, What is Universal Pragmatics?, in JURGEN HABERMAS, COMMUNICATION AND THE EvOluTION OF SOCIETY (T. McCarthy trans., 1979).

231. JuRgen Habermas, KNOWLEDGE AND Human INTERESTS 317 (Jeremy Shapiro trans., 1971).

232. BOAL, ET. AL., supra note 157 , at 86 n. 75 . 
"emerging terrorists"; forever and everywhere threatened by the plague, all the better to pursue the political dream of the plague.

The merits or demerits of Guantanamo Bay as a detention site is beside the point, an incidental issue in the larger struggle over the future of globalization and America's vision of its place within that future. Guantanamo-style detention signifies, despite how it may betray our values, our need for military hegemony, a military hegemony that could hardly be justified where the only threat to American hegemony in a globalized marketplace is the surging economic strength of China or a unified Europe. It is in that sense that the war on terror serves Guantanamo, rather than the other way around. What Guantanamo-style detention ratifies-and thus the key to its true function, which transcends its merits or demerits as an instrument of policy in our so-called war on terror-is an ontology manufactured through a resurgent sovereignty, one marked by a dividing line between compliant laborers and consumers on the one hand, and on the other, violent terrorists who are said to hate our liberty-loving way of life. Guantanamo-style detention may betray our values, but it inscribes in our pax Americana consciousness the existence of an evil, a plague, that must be vanquished. ${ }^{233}$ It may betray our professed self-identity, but it inscribes the major duality of our time, the happy consumer in a globalized wonderland and the religiously fanatical terrorist bent on sabotaging the entire edifice. Hamdi's veil of administrative decency, then, can mute the betrayal, alleviate a bit the sting of it, all the while silently deepening that inscription, through its Weberian rationality, through its means-ends rationality that characterizes a system-sphere logic that Habermas warns us against.

It is upon this platform of critique that one can understand Hamdi to be, not a bracketed scenario, a case arising from a state of exception, but rather an ominous cultural document of our post-9/11 anxieties, an expression and reinforcement of the Western quest for control and domination, born of the Enlightenment, that has, centuries later, generated this "difficult time in our Nation's history."

233. It is no surprise that the quandary over torturing captured terrorists has come to infiltrate our public sphere. Torture is not really an information-gathering tool. It is, at its core, a form of vanquishing the victim. See ElaINE SCARRY, THE BODY IN PAIN 29 (1985). Torture, then, is in keeping with the essential quest of the so-called war on terror. And insofar as it accomplishes this vanquishing through the communication of complete domination and control - the ability to inflict and withhold pain - torture is the dark underbelly of the Enlightenment. See also Darius Rejali, TORTURE AND Democracy (2008). 